\title{
Time scales of large volume silicic magma systems: Sr isotopic systematics of phenocrysts and glass from the Bishop Tuff, Long Valley, California
}

\author{
John N. Christensen ${ }^{1, *}$ and Donald J. DePaolo ${ }^{1,2}$ \\ ${ }^{1}$ Berkeley Center for Isotope Geochemistry, Department of Geology and Geophysics, University of California, Berkeley, CA 9472, USA \\ ${ }^{2}$ Earth Sciences Division, Lawrence Berkeley Laboratory, Berkeley, CA 94720, USA
}

Received November 14, 1991/Accepted June 29, 1992

\begin{abstract}
The initial Sr isotopic compositions of glass and mineral separates from the $0.74 \mathrm{Ma}$ Bishop Tuff ashflow in eastern California were determined to investigate the time scales of magmatic processes in a large silicic system. It was found that there is substantial isotopic heterogeneity, both between eruptive units and between glass and phenocryst phases of individual units. The first-erupted, lower temperature units generally have higher initial ${ }^{87} \mathrm{Sr} /{ }^{86} \mathrm{Sr}$ than later crupted, higher temperature units. Within each unit, feldspar phenocrysts have the lowest ${ }^{87} \mathrm{Sr} /{ }^{86} \mathrm{Sr}$, associated glass has higher ${ }^{87} \mathrm{Sr} /{ }^{86} \mathrm{Sr}$, and biotite phenocrysts have the highest ${ }^{87} \mathrm{Sr} /{ }^{86} \mathrm{Sr}$. These isotopic differences were produced by processes in the magma chamber and not by post-eruptive alteration. Two samples were similar Fe-Ti oxide temperatures but from widely separated localities have nearly identical $\mathrm{Sr}$ isotopic characteristics, indicating the existence of compositionally uniform layers of substantial volume within the chamber. Trace element data indicate that the feldspars crystallized from a liquid represented by the associated glass, and that the feldspar-glass pairs are not accidental. The rhyolitic liquids of the Bishop tuff magma chamber apparently experienced increasing ${ }^{87} \mathrm{Sr} /{ }^{86} \mathrm{Sr}$ at a rate too fast for feldspar phenocrysts to remain in isotopic equilibrium. The increasing ${ }^{87} \mathrm{Sr} /{ }^{86} \mathrm{Sr}$ is caused primarily by radioactive decay of ${ }^{87} \mathrm{Rb}$ in the high- $\mathrm{Rb} / \mathrm{Sr}$ liquids and not primarily by assimilation of radiogenic wall-rock material. A self-consistent model can be constructed to account for all of the isotopic data except for those on biotite phenocrysts. The time scale for evolution of the system is bounded on the high side at about $500 \mathrm{ky}$ by observations made on precaldera lavas, and on the low side at approximately $300 \mathrm{ky}$ by the time necessary to establish homogeneous layers in an actively differentiating chamber. The deduced time scale is consistent with model $\mathrm{Rb}-\mathrm{Sr}$ ages, which date the differentiation of low temperature liquids from higher temperature liquids, and is compatible with the observed isotopic disequilibrium between feldspars
\end{abstract}

* Present address: Department of Geological Sciences, University of Michigan, 1006 C.C. Little Bldg., Ann Arbor, MI 48109, USA Correspondence to: J.N. Christensen and glass because of the low diffusivity of $\mathrm{Sr}$ in fieldspars $\left(<10^{-16} \mathrm{~cm}^{2} / \mathrm{s}\right)$. The prolonged (about $500 \mathrm{ky}$ ) evolution of the Bishop Tuff system was facilitated by a large influx of basaltic material (about $10^{-2} \mathrm{~km}^{3} / \mathrm{y}$ ) to the base of the system, which compensated for diffusive heat loss from the top and allowed large volumes of magma to maintain low crystal contents for $>3 \times 10^{5}$ years. The silicic-magma production rate within the Bishop Tuff magma chamber is estimated to be $10^{-3} \mathrm{~km}^{3} / \mathrm{y}$. The growth rate of alkali feldspar is estimated to be about $10^{-14} \mathrm{~cm} / \mathrm{s}$ based on the $\mathrm{Sr}$ isotopic difference between sanidine and glass of the lower Bishop Tuff. The biotite population is inferred to be partially $(<50 \mathrm{ppm})$ xenocrystic, the xenocrysts being introduced to the chamber less than one year prior to eruption.

\section{Introduction}

This study presents $\mathrm{Rb}-\mathrm{Sr}$ isotopic data for samples of phenocrysts and glass from the Bishop Tuff, a large volume silicic ashflow erupted from the Long Valley caldera system at $0.74 \mathrm{Ma}$ (Gilbert 1938; Sheridan 1965; Hildreth 1977,1979 ). This study was originally undertaken to use high precision $\mathrm{Sr}$ isotopic measurements to refine the age of the eruption, since the Bishop Tuff age is an important datum in the geomagnetic time scale (Dalrymple et al. 1965; Dalrymple 1980; Izett 1982; Hurford and Hammerschmidt 1985). In the process it was found that there is a rich phenomenology of isotopic variability between phenocryst phases and associated volcanic glass, and that these variations place unique constraints on time scales of the differentiation processes in this silicic magma system (Christensen and DePaolo 1987; Christensen 1987).

$\mathrm{Sr}$ isotopic variability within the Bishop Tuff was previously noted by Noble and Hedge (1970) and by Halliday et al. (1984), and was attributed to assimilation (Noble and Hedge 1970; Christiansen 1983) and to postemplacement low temperature interaction with ground water (Halliday et al. 1984). In this work we show that these cxplanations are insufficient, and that the isotopic 
variations were produced in the magma chamber. Halliday et al. (1989) also report isotopic variations among lavas that preceded eruption of the Bishop Tuff; and reach conclusions compatible with the data and interpretations presented here.

The Cenozoic volcanic history of the Long Valley region is reviewed in Bailey et al. (1976); Gilbert et al. (1968); Huber and Rinehart (1967) and Rinehart and Ross (1964). The earliest Cenozoic volcanic sequence in the area is a complex of 11 to $8 \mathrm{Ma}$ andesite, basalt, dacite and rhyolite centered on the Bodie hills (Chesterman 1968; Gilbert et al. 1968; Silberman and Chesterman 1972). Volcanism resumed with the eruption of basalt and andesite at 4 to $3.5 \mathrm{Ma}$ followed by dacite/quartz latite domes at San Joaquin Mountain, Two Teats and Bald Mountain at 3.0 to $2.7 \mathrm{Ma}$ (Bailey 1974). The first activity that may be directly associated with the Bishop Tuff magma chamber was the building of Glass Mountain, a complex of high-silica rhyolite flows and pyroclastics comprising at least $15 \mathrm{~km}^{3}$, erupted between $2.1 \mathrm{My}$ and 0.8 My (Metz and Mahood 1985, 1991). The eruption of the $700 \mathrm{~km}^{3}$ (Hildreth and Mahood 1986; a minimum estimate) of Bishop Tuff at $0.74 \mathrm{Ma}$ followed closely (sixty to one hundred thousand years) the last eruption at Glass Mountain.

The Bishop Tuff is a chemically zoned high-silica rhyolite air fall and ash flow, eruption of which was accompanied by the formation and collapse of Long Valley caldera (Hildreth 1977, 1979). The post-Bishop Tuff volcanic activity is described by Bailey et al. (1976). The Bishop Tuff eruption was followed by resurgent doming and the eruption between 0.73 and $0.63 \mathrm{Ma}$ within the caldera of high-temperature, fluid, crystal-poor rhyolite. At approximately $0.5 \mathrm{Ma}, 0.3 \mathrm{Ma}$, and $0.1 \mathrm{Ma}$, domes of pumiceous, crystal-rich rhyolite were built in the caldera moat. Peripheral to the inferred location of the caldera ring fault are a series of rhyodacites, the most prominent of which is Mammoth Mountain on the southwest edge of the caldera. The Mammoth Mountain complex consists of superimposed domes and flows of rhyodacite, dacite and minor rhyolite, constructed between $0.18 \mathrm{Ma}$ and $0.05 \mathrm{Ma}$ (Koeppen 1983). Other rhyodacite domes were emplaced at Deadman Creek (including olivine-bearing quartz latite of Rinehart and Ross 1964) on the northwest and at the base of Glass Mountain. Overlapping in time with the rim rhyodacites were eruptions of basalt and andesite within the caldera, mainly within the western moat. Ages range from $0.22 \mathrm{Ma}$ to $0.06 \mathrm{Ma}$, though older (the $0.6 \mathrm{Ma}$ ? Devil's Post pile basaltic andesite) and younger $(0.075-0.02 \mathrm{Ma}$ trachyandesite of June Lake) flows occur just outside the caldera. The latest volcanic activity includes the Inyo craters and domes within the caldera (Miller 1985) and the northward trending arc of Mono craters (Wood 1977).

\section{Samples}

Samples of Bishop Tuff (BT) were selected to cover the range of Hildreth's Fe-Ti oxide temperatures, using samples that show little or no evidence of alteration and hydration. Where possible, samples of vitrophyre were chosen to minimize alteration via hydration, to which pumice samples can be more susceptible. Sample BT-6 is from

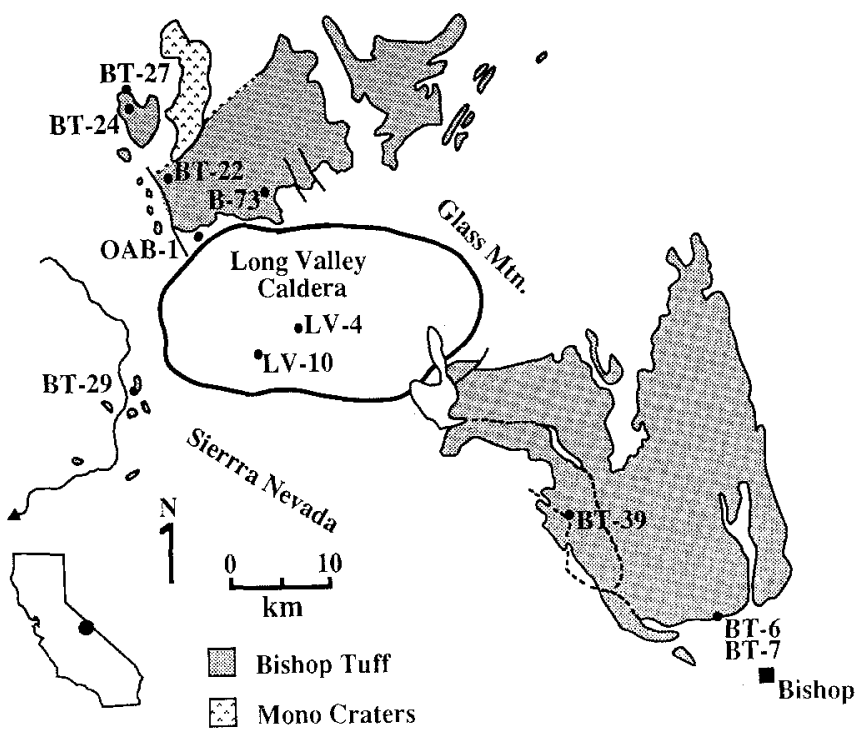

Fig. 1. Location map of the analyzed samples showing the general outcrop distribution of the Bishop Tuff. The inferred outline of Long Valley caldera is shown by the heavy line. Also shown is Glass Mountain, a pre-caldera rhyolitic center and the post-caldera Mono Craters. After Hildreth and Mahood 1986

the initial airfall $\left(\mathrm{T}=722^{\circ} \mathrm{C}\right)$; samples BT-7, BT-29 and BT-39 are from the lower unit $\left(\mathrm{T}=725^{\circ} \mathrm{C}\right)$; samples BT-22, BT-27 and B-73 are from the middle unit $\left(\mathrm{T}=760^{\circ} \mathrm{C}\right)$; and BT-24 is from the upper unit $\left(\mathrm{T}=790^{\circ} \mathrm{C}\right)$. The present stratigraphy represents an inversion of the original stratigraphic order within the magma chamber.

All samples of Bishop Tuff contain subequal amounts of sanidine and quartz, lesser amounts (by approximately one-third) of plagioclase, and minor amounts of biotite and Fe-Ti oxides. Orthopyroxene and clinopyroxene are present in trace amounts in the middle and upper portions of the tuff but are absent in the lower unit and from the airfall. Hand sample descriptions and locations are given in Appendix 2. Sample localities are shown on Fig. 1.

\section{Analytical methods}

Samples were crushed, sieved, cleaned ultrasonically in distilled water, and rinsed with distilled water and alcohol. The separation techniques used varied somewhat as dictated by the sample and by initial results. Initially, the 40-60 mesh and 60-100 mesh size fractions were treated with bromoform/dimethylsulfoxide mixtures to create glass, sanidine, quartz + plagioclase, and heavy mineral separates. In the case of the single fiamme from BT-22, magnetic separation was used to separate the dark (magnetite-rich?) rim glass from the white core glass. The mineral separates were cleaned by hand under a low power binocular microscope. Sanidine separates of the BT-22 fiamme and BT-24 pumice were found to be deficient in K relative to Hildreth's (1977) electron microprobe analyses, due to the presence of quartz and plagioclase. Subsequently, sanidine separates for BT-27, BT-29, and BT-39 were made by hand-plucking phenocrysts of sanidine directly from the rock. These separates were processed in heavy liquid to ensure purity. Likewise, glass was picked directly from fiamme of these samples. The glass was sonified, cleaned, crushed and processed in heavy liquids to remove any phenocrysts. The pumice from BT -6 and BT-7 was separated on the basis of texture and crushed. Mineral separates were made using the bromoform/DMSO density separation technique, except that sanidine was hand-picked from the sanidine-density separate. This resulted in K analyses that agreed well with Hildreth's (1977) analyses. B-73 mineral separates were made from a crushed whole-rock sample, but glass was not analyzed. Samples LV-10 and OAB-1 were analyzed as whole-rock samples. Sample LV-4 was crushed, sieved, 
cleaned and processed in heavy liquids to produce a glass separate. The purity of this separate was checked in oils under a petrographic microscope.

Typically for feldspar, a $100 \mathrm{mg}$ sample of the separate was weighed for dissolution. For the lower temperature glasses with low Sr concentrations, approximately $500 \mathrm{mg}$ of glass was used. The entire separates of biotite were used for analysis; sample masses ranged from 60 to $80 \mathrm{mg}$. Approximately $200 \mathrm{mg}$ of the whole-rock powders were weighed for dissolution. Samples were spiked for $R b$ and $\mathrm{Sr}$ after dissolution; and analyzed for isotopic composition on a single-collector VG 54E mass spectrometer at UCLA. $\mathrm{Rb}$ and $\mathrm{Sr}$ concentrations and ${ }^{87} \mathrm{Sr} /{ }^{86} \mathrm{Sr}$ were determined on the same aliquot. Total chemistry blanks were approximately $200 \mathrm{pg}$ for $\mathrm{Sr}$ and about $500 \mathrm{pg}$ for $\mathrm{Rb}$. During the period of the analyses, NBS 987 was analyzed as $0.71032 \pm 1$. An exponential discrimination correction (Marshall and DePaolo 1982) was applied to the data which was normalized to a value of the ${ }^{86} \mathrm{Sr} /{ }^{88} \mathrm{Sr}$ of 0.1194 .

\section{Results}

The $\mathrm{Rb}$ and $\mathrm{Sr}$ concentrations in phenocryst phases and glass samples were used to assess whether a particular phenocryst sample crystallized from the glass associated with it. Concentrations of $\mathrm{Rb}$ and $\mathrm{Sr}$ from spiked runs and concentrations of $\mathrm{K}, \mathrm{Sm}$ and $\mathrm{Nd}$ from mixed spike runs are presented in Table 1. Also included are INAA analyses of corresponding samples made by Hildreth (1977). In general the concentrations of Sm and $\mathrm{Nd}$ determined in this study agree well with the INAA analyses.
Nearly all sanidine separates have $\mathrm{K}_{2} \mathrm{O}$ concentrations that fall in the range of Bishop Tuff sanidine, $10.42-12.23 \%$ found by Hildreth (1977), and agree well in detail for corresponding samples (see Table 1). Sanidine separates from BT-22 and BT-24 fall significantly below this range with $5.43 \%$ and $7.97 \% \mathrm{~K}_{2} \mathrm{O}$ respectively, due to inefficient separation methods as noted already. As expected the $\mathrm{K}_{2} \mathrm{O}$ contents of the plagioclase + quartz separates fall below the range $1.08-1.39 \% \mathrm{~K}_{2} \mathrm{O}$ for plagioclase as measured by Hildreth (1977).

Our approach is to use the measured $\mathrm{Rb}$ and $\mathrm{Sr}$ concentrations in glass and mineral separates to calculate apparent solid/liquid distribution coefficients. This require corrections for the impurity of the mineral separates. For plagioclase, concentrations of $\mathrm{Rb}$ and $\mathrm{Sr}$ were corrected assuming simple dilution by quartz with zero $p$ pm $\mathrm{Rb}$ and $\mathrm{Sr}$ and assuming that the $\mathrm{K}_{2} \mathrm{O}$ content of the plagioclase was the same as upper BT plagioclase, approximately 1.2\% (Hildreth 1977). The sanidine separates of BT-22 and BT-24 are not used to calculate $\mathrm{Rb}$ and $\mathrm{Sr}$ sanidine/glass distribution coefficients, because it was not possible to determine accurately the proportions of admixed plagioclase versus quartz. Calculated $\mathrm{Sr}$ and $\mathrm{Rb}$ mineral/glass distribution coefficients for sanidine, plagioclase and biotite based on best separates are tabulated in Table 2, along with distribution coefficients for high silica rhyolites from Nash and Crecraft (1985) for comparison.

Table 1a. Concentrations of K, Sm and Nd from mixed spike runs compared with Hildreth's data

\begin{tabular}{|c|c|c|c|c|c|c|c|c|}
\hline \multirow[b]{2}{*}{ Sample } & \multicolumn{3}{|c|}{ Data from this study } & \multirow[b]{2}{*}{$\operatorname{Sm}(\mathrm{ppm})^{\mathrm{a}}$} & \multirow[b]{2}{*}{$\begin{array}{l}\text { Hildreth } \\
\text { sample no. }\end{array}$} & \multicolumn{2}{|c|}{ Data from Hildreth (1977) } & \multirow[b]{2}{*}{$\operatorname{Sm}(\mathrm{ppm})^{\mathrm{d}}$} \\
\hline & Material & $\mathrm{K}_{2} \mathrm{O}$ wt. $\%$ & $\mathrm{Nd}(\mathrm{ppm})^{\mathrm{a}}$ & & & $\mathrm{K}_{2} \mathrm{O}$ wt. $\%{ }^{\mathrm{b}}$ & $\mathrm{Nd}(\mathrm{ppm})^{\mathrm{d}}$ & \\
\hline BT -6 & Glass & 6.3 & 16.2 & 4.8 & B-83 & 5.3 & 17.7 & 4.8 \\
\hline BT -6 & Sanidine & 11.2 & - & - & & 10.7 & 0.65 & 0.118 \\
\hline BT-39 & Glass & 6.9 & 16.3 & 4.0 & B-81 & & - & - \\
\hline BT-39 & Sanidine & 11.3 & 1.0 & 0.04 & & 11.32 & - & - \\
\hline BT-29 & Glass & 7.1 & - & - & B129 & - & & - \\
\hline BT -29 & Sanidine & 11.8 & 2.7 & 0.1 & & - & - & - \\
\hline BT -7 & Sanidine & 11.9 & - & - & & - & - & - \\
\hline B-73 & Sanidine & 9.9 & 0.76 & 0.1 & B-73 & 12.0 & 1.3 & 0.167 \\
\hline B-73 & Plag + qtz & 0.95 & 1.57 & 0.19 & & $1.39^{\circ}$ & - & - \\
\hline B-73 & Biotite & & - & - & & 9.4 & 60 & 5.47 \\
\hline BT -22 & Glass core & 5.6 & 23.7 & 3.1 & - & - & - & - \\
\hline BT-22 & Glass rim & 5.6 & 24.6 & 3.4 & - & - & - & - \\
\hline BT-22 & Sanidine & 5.4 & 9.0 & 0.9 & - & - & - & \\
\hline BT-22 & Plag + qt $z$ & 0.6 & 5.4 & 0.5 & - & $\cdots$ & - & - \\
\hline BT-22 & Biotite & 8.0 & 80.5 & 6.3 & - & - & - & - \\
\hline BT-27 & Glass & 5.75 & 25.6 & 3.4 & B-79 & 5.73 & 25.7 & 3.22 \\
\hline BT-27 & Sanidine & 10.8 & 0.33 & - & & 11.2 & - & 0.037 \\
\hline ВТ-27 & Biolite A & 8.1 & 55.0 & 5.9 & & 9.24 & 69 & 6.04 \\
\hline BT-27 & Biotite B & - & 46.3 & 6.2 . & & & & \\
\hline ВТ-24 & Glass & 5.5 & 23.9 & 3.1 & B-77 & 6.0 & 32.7 & 3.32 \\
\hline ВT-24 & Sanidine & 8.0 & - & - & & 10.9 & - & 0.045 \\
\hline BT -24 & Plag + qtz & 0.9 & 9.4 & 0.8 & & 1.17 & 2.4 & 0.23 \\
\hline OAB-1 & Whole rock & 1.9 & 25.3 & 4.6 & - & - & - & - \\
\hline LV-10 & Whole rock & 1.5 & 40.5 & 7.3 & - & - & - & - \\
\hline LV-4 & Glass & 4.8 & 19.3 & 2.9 & - & - & - & - \\
\hline
\end{tabular}

a By isotope dilution

b Minerals by microprobe, glass by INAA

Quartz free

d By INAA 
Table $\mathbf{1 b} . \mathrm{Rb}$ and $\mathrm{Sr}$ isotope data

\begin{tabular}{|c|c|c|c|c|c|c|}
\hline Sample & Material & $\mathrm{Rb}(\mathrm{ppm})$ & $\mathrm{Sr}(\mathrm{ppm})$ & ${ }^{87} \mathrm{Rb} /{ }^{86} \mathrm{Sr}$ & $\left({ }^{87} \mathrm{Sr} /{ }^{86} \mathrm{Sr}\right)_{\mathrm{m}}^{\mathrm{g}}$ & $\left({ }^{87} \mathrm{Sr} /{ }^{86} \mathrm{Sr}\right)_{0.74 \mathrm{My}}$ \\
\hline BT- 6 & Sanidine & 118.1 & 23.52 & 14.53 & $0.70684 \pm 2$ & $0.70669 \pm 2$ \\
\hline BT -39 & Sanidine & 119.3 & 21.05 & 16.40 & $0.70670 \pm 3$ & $0.70653 \pm 3$ \\
\hline BT -29 & Glass & 192.3 & 2.019 & 275.6 & $0.70975 \pm 2$ & $0.70685 \pm 7$ \\
\hline BT-29 & Sanidine & 118.4 & 20.75 & 16.52 & $0.70672 \pm 3$ & $0.70654 \pm 3$ \\
\hline & & & & & $0.70604 \pm 4$ & $0.70603 \pm 4$ \\
\hline B-73 & Plag + qtz & 3.86 & 47.80 & 0.234 & $0.70609 \pm 2$ & $0.70609 \pm 2$ \\
\hline B-73 & Biotite & 1107 & 21.53 & 148.4 & $0.70876 \pm \overrightarrow{ \pm} 4$ & $0.70720 \pm 7$ \\
\hline $\mathrm{BT}-22$ & Glass core & 133.5 & 28.87 & 13.38 & $0.70623 \pm 4$ & $0.70609 \pm 4$ \\
\hline BT -22 & Glass rim & 142.5 & 19.78 & 20.84 & $0.70635 \pm 6$ & $0.70614 \pm 6$ \\
\hline BT-22 & Sanidine & 33.77 & 360.8 & 0.27 & $0.70602 \pm 3$ & $0.70602 \pm 3$ \\
\hline BT-22 & Plag + qtz & 3.635 & 204.4 & 0.05 & $0.70601 \pm 3$ & $0.70601 \pm 3$ \\
\hline BT -27 & Biotite $\mathbf{B}^{f}$ & 1114 & 22.53 & 143.2 & $0.71021 \pm 3$ & $0.70870 \pm 5$ \\
\hline BT-24 & Glass & 100.1 & 46.11 & 6.28 & $0.70662 \pm 3$ & $0.70655 \pm 3$ \\
\hline BT-24 & Sanidine & 52.26 & 364.8 & 0.42 & $0.70603 \pm 2$ & $0.70603 \pm 2$ \\
\hline BT-24 & Plag + qtz & 5.39 & 304.3 & 0.05 & $0.70601 \pm 2$ & $0.70601 \pm 2$ \\
\hline $\mathrm{OAB}-1$ & Whole rock & 35.24 & 915.8 & 0.11 & $0.70613 \pm 2$ & 0.70612 at $2.87 \mathrm{My}^{\mathrm{h}}$ \\
\hline LV -10 & Whole rock & 22.49 & 940.8 & 0.07 & $0.70625 \pm 3$ & 0.70625 at $62 \mathrm{kyr}^{\mathrm{h}}$ \\
\hline LV-4 & Rhyolitic glass & 141.0 & 99.72 & 4.09 & $0.70665 \pm 3$ & 0.70661 at $0.68 \mathrm{My}^{\mathrm{h}}$ \\
\hline
\end{tabular}

e $<30>40$ mesh size fraction

f $<40>60$ mesh size fraction

g Errors are $2 \sigma$ in the last digit

h Ages from Bailey et al. 1976

Table 2. Apparent glass/mineral distribution coefficients for $\mathrm{Sr}, \mathrm{Rb}, \mathrm{Nd}, \mathrm{Sm}$

\begin{tabular}{|c|c|c|c|c|c|c|c|c|}
\hline & \multicolumn{4}{|c|}{ This study } & \multicolumn{4}{|c|}{ Nash and Crecraft (1985) } \\
\hline & $\mathrm{D}_{\mathrm{Sr}_{\mathrm{r}}}$ & $\mathrm{D}_{\mathrm{Rb}}$ & $\mathrm{D}_{\mathrm{Nd}}$ & $\mathrm{D}_{\mathrm{Sm}}$ & $\mathrm{D}_{\mathrm{S}_{\mathrm{r}}}$ & $D_{R b}$ & $\mathrm{D}_{\mathrm{Nd}}$ & $\mathrm{D}_{\mathrm{Sm}}$ \\
\hline Sanidine & Middle BT 9.2 & 0.54 & $\sim 0.03^{\mathrm{a}}$ & $\sim 0.03^{\mathrm{a}}$ & $4.5-7.3$ & $1.2-1.8$ & $0.03-0.04$ & 0.02 \\
\hline Plagioclase & 11.5 & 0.053 & 0.48 & 0.33 & $6.8-1.3$ & $0.06-0.11$ & $0.14-0.19$ & $0.11-0.15$ \\
\hline Biotite & 0.98 & $4.8-9.0$ & $1.8-3.4$ & $1.7-2.0$ & $0.29-0.53$ & $2.3-4.1$ & $0.9-5.7$ & $1.0-4.3$ \\
\hline
\end{tabular}

a Calculated from B-73 sanidine and BT-27 glass

Sr concentration data and $\mathrm{Rb} / \mathrm{Sr}$ ratios for mineral and glass separates of BT samples are shown in Fig. 2 in the stratigraphic order they would have had in the magma chamber. Age-corrected ${ }^{87} \mathrm{Sr} /{ }^{86} \mathrm{Sr}$ ratios are presented in a similar fashion in Fig. 3. Concentrations of $\mathrm{Sr}$ and $\mathrm{Rb}$ and sanidine/liquid distribution coefficients are remarkably consistent for lower $\left(725^{\circ} \mathrm{C}\right)$ Bishop Tuff samples BT-39 and BT-29. The $\mathrm{D}_{\mathrm{Sr}}$ for sanidine calculated from data from BT-27 and BT-24 (middle and upper BT) is similar to that calculated for the lower BT samples. This indicates that the sanidine of the lower BT, and presumably the other phenocrysts as well crystallized from an already differentiated liquid. The consistency of the calculated $\mathrm{D}_{\mathrm{Sr}}$ for sanidine, despite the 10 times greater concentration of $\mathrm{Sr}$ in middle and upper BT glass compared to lower BT glass, precludes significant mixing of high-Sr and low-Sr portions of the magma chamber after precipitation of the observed phenocrysts. This is in agree- ment with the fluid dynamical calculations of Blake and Ivey (1986) which indicate that eruption of the Bishop Tuff would sample the contents of the chamber with little mixing. The consistency of $\mathrm{D}_{\mathrm{Sr}}$ also indicates that crystal settling within the magma chamber was not an important differentiation mechanism in accord with the conclusion reached by Hildreth (1979).

The $\mathrm{Sr}$ concentration of the glass from the air-fall sample (BT-6) is high relative to the trend of decreasing concentration with decreasing $\mathrm{Fe}-\mathrm{Ti}$ oxide temperature, and high relative to the $\mathrm{Sr}$ concentration of the coexisting sanidine. This sample also has an extremely high calculated initial ${ }^{87} \mathrm{Sr} /{ }^{86} \mathrm{Sr}$ ratio (Fig. 3). Although we believe these properties are primary, we cannot offer a strong argument that this sample has not been affected by posteruption weathering. In particular one sample, the air-fall at the BT-6 locality has a high content of $\mathrm{H}_{2} \mathrm{O}+(2-3 \%$; Hildreth 1977). Although, several samples of the lower 

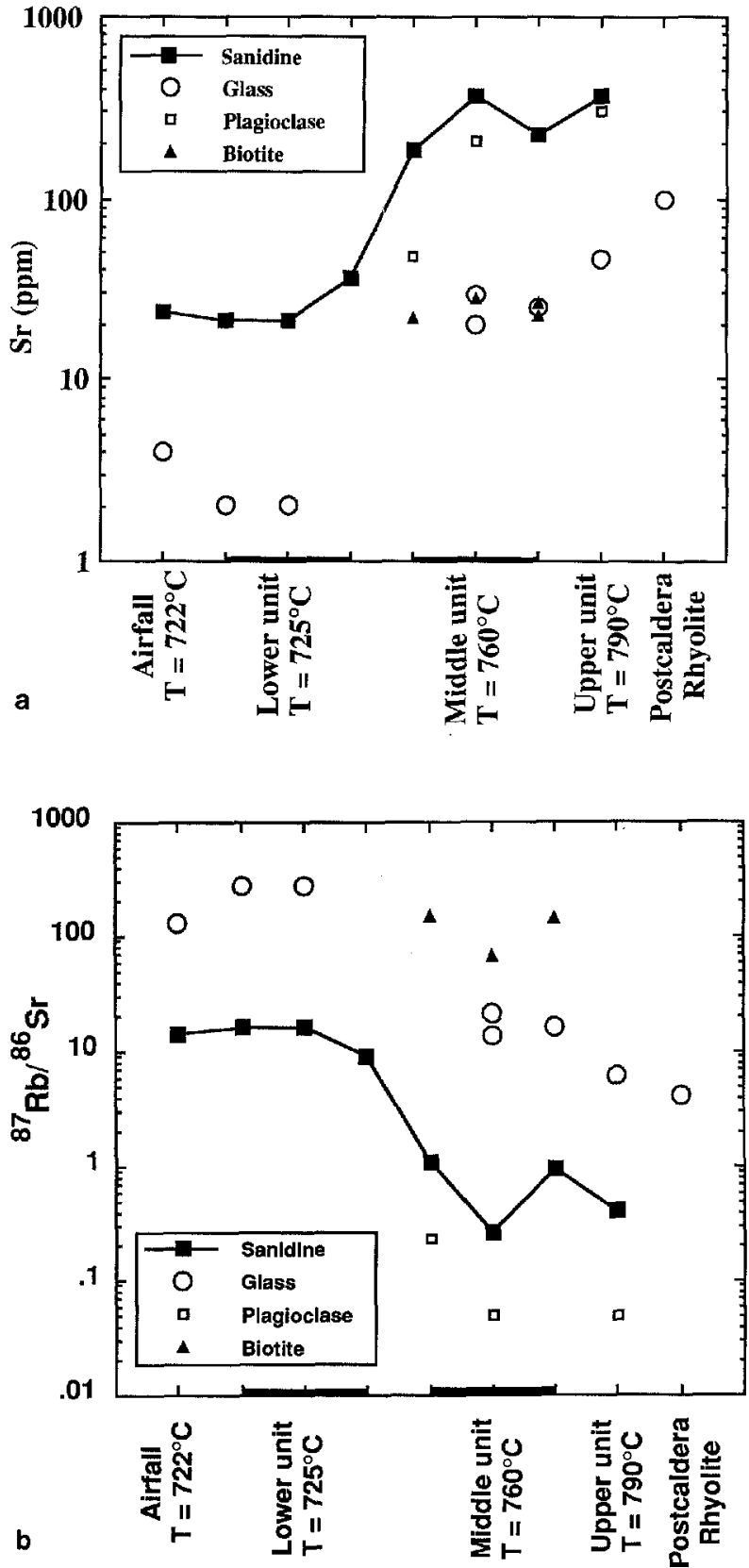

Fig. 2a, b. The $\mathrm{Sr}$ concentrations a and ${ }^{87} \mathrm{Rb} /{ }^{86} \mathrm{Sr} \mathbf{b}$ from Table $1 \mathrm{~b}$ of glass and mineral separates for samples of Bishop Tuff and a postcaldera early rhyolite. The Bishop Tuff samples are shown in the stratigraphic order they had within the Long Valley magma chamber. Approximate Fe-Ti oxide temperatures are from Hildreth (1977)

and middle BT were analyzed, so that we have a check for consistency between samples, for the BT air-fall we have only the single sample.

\section{Isotopic data}

All samples of the Bishop Tuff show a Sr isotopic difference between glass and phenocrysts at the time of the eruption at $0.74 \mathrm{Ma}$ (Fig. 3). For the lower BT there is a difference of $3.4 \times 10^{-4}$ in the ${ }^{87} \mathrm{Sr} /{ }^{86} \mathrm{Sr}$ ratio between glass and

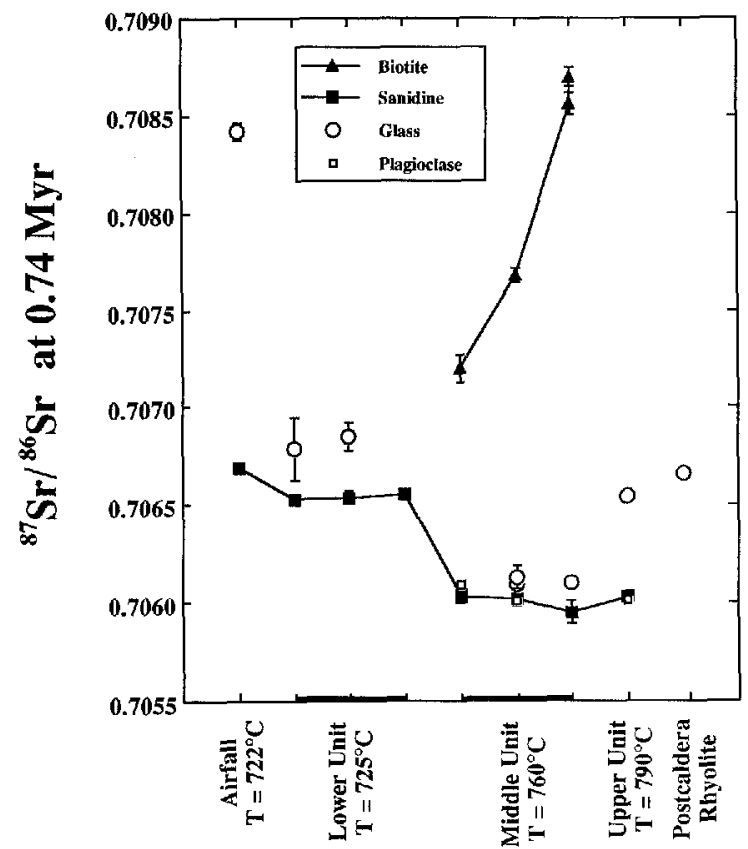

Fig. 3. The ${ }^{87} \mathrm{Sr} /{ }^{86} \mathrm{Sr}$ ratios (see Table 1b) of Bishop Tuff glass and mineral separates corrected to values at the time of eruption at $0.74 \mathrm{My}$. Errors of initial ratios (see Table $1 \mathrm{~b}$ ) include the uncertainties in the age of the BT $(10 \mathrm{ky}),{ }^{87} \mathrm{Rb} /{ }^{86} \mathrm{Sr}(0.5 \%)$ and in measured ${ }^{87} \mathrm{Sr} /{ }^{86} \mathrm{Sr}$. The samples are shown in the stratigraphic order they had in the Long Valley magma chamber. Approximate Fe-Ti oxide temperatures are from Hildreth (1977)

sanidine using the best data. The middle BT is characterized by a difference of approximately $1 \times 10^{-4}$ between glass and feldspar (sanidine and plagioclase). There is also a difference between lower BT glass and middle BT feldspar of $5.3 \times 10^{-4}$ at eruption. The highest temperature sample (BT-24) of upper BT pumice contains feldspar that has an initial ratio indistinguishable from the middle BT feldspar, but the glass from BT-24 has an elevated ${ }^{87} \mathrm{Sr} /{ }^{86} \mathrm{Sr}$ ratio compared to middle BT glass so that its feldspar-glass difference is $5.3 \times 10^{-4}$.

The greatest isotopic differences for $\mathrm{Sr}$ are between glass and biotite (Fig. 3). Four samples of biotite from middle BT samples have initial ratios from 0.7072 to 0.7087 compared to 0.7061 in the glass. Care was taken to produce clean separates by hand picking and no obviously xenocrystic biotite was identifiable. In thin section the biotite is euhedral, with a reddish-brown to yellow-brown pleochroism; many crystals have regions or layers of light red color. Hildreth (1977) had difficulty finding a truly homogeneous sample of biotite, only five of fifty samples had a homogeneous population of biotite. The Rb concentrations measured by Hildreth vary from $335 \mathrm{ppm}$ to $2800 \mathrm{ppm}$ and do not correlate well with temperature. The samples measured for this study show a restricted range of Sr concentration, 21.5 to $27.8 \mathrm{ppm}$; $\mathrm{Rb}$ concentrations vary from 627 to $1236 \mathrm{ppm}$. All of these samples are from vitrophyre, and all have the same Fe-Ti oxide temperature. Calculated biotite/glass $\mathrm{Sr}$ distribution coefficients are about 1 for these samples.

The observed high ratios in the biotites are not caused by weathering. The biotite samples come from an unaltered 
glass matrix that has approximately the same concentration of $\mathrm{Sr}$ as the biotite and is probably more susceptible to alteration. Loss of $\mathrm{Sr}$ by biotite would result in lower calculated initial ratios because of an increased ${ }^{87} \mathrm{Rb} /{ }^{86} \mathrm{Sr}$ ratio. Gain of high ${ }^{87} \mathrm{Sr} /{ }^{86} \mathrm{Sr}$ strontium does not seem likely since such $\mathrm{Sr}$ should also affect the glass at least as much as the biotite.

The biotite from BT-22 is from a single fiamme and should avoid the problem of accidental lithic and mineral fragments that may be picked up by the flow. The initial ${ }^{87} \mathrm{Sr} /{ }^{86} \mathrm{Sr}$ ratio for that sample, 0.70769 , is in fact higher than that of the biotite from the whole-rock of B-73 $(0.70720)$, which may contain accidentally included biotite. The BT-22 biotite data indicate that the biotite sample acquired the higher ratios in the magma chamber or possibly in the volcanic conduit on the way to the surface, but not during or after emplacement at the surface.

Samples of pre-(OAB-1) and post-caldera (LV-10) alkali basalt have ${ }^{87} \mathrm{Sr} /{ }^{86} \mathrm{Sr}$ ratios of 0.70612 and 0.70625 respectively, slightly higher than middle $\mathrm{BT}$ ratios. The post-caldera rhyolite has a ${ }^{87} \mathrm{Sr} /{ }^{86} \mathrm{Sr}$ ratio of 0.70661 at the time of its eruption at $0.64 \mathrm{My}$ which is also higher than the middle BT.

It is important to note that BT-29 and BT-39 have essentially identical concentrations of $\mathrm{Sr}$ and $\mathrm{Rb}$ in sanidine and identical concentrations in glass (Table 1, Fig. 2). In addition, the ${ }^{87} \mathrm{Sr} /{ }^{86} \mathrm{Sr}$ ratios at $0.74 \mathrm{My}$ are identical in the sanidine of BT-29 and BT-39, and are identical (within error) in the glass separates (Fig. 3). These two samples are from localities separated by $50 \mathrm{~km}$. This observation is significant for two reasons. First it indicates that a substantial volume of the Bishop Tuff magma (tens of cubic kilometers) was highly homogeneous. This implies that the Bishop Tuff chamber was compositionally layered with respect to $\mathrm{Rb}, \mathrm{Sr}$ and ${ }^{87} \mathrm{Sr} /{ }^{86} \mathrm{Sr}$, rather than continuously zoned as suggested by Hildreth $(1977,1979$, 1981). Samples of middle BT $\left(760^{\circ} \mathrm{C}\right)$ also have fairly consistent $\mathrm{Rb}$ and $\mathrm{Sr}$ concentrations and ${ }^{87} \mathrm{Sr} /{ }^{86} \mathrm{Sr}$ ratios and probably represent another layer. There was insufficient sampling to delineate intervening layers. Secondly, the consistency observed in the lower BT samples further demonstrates that they have been unaffected by posteruption alteration.

In contrast to the lower BT samples, air-fall pumice samples have a much greater range in $\mathrm{Sr}, \mathrm{Rb}$ concentration and initial ${ }^{87} \mathrm{Sr} /{ }^{86} \mathrm{Sr}$ in the glass and sanidine. Halliday et al. 1984 obtained an initial ${ }^{87} \mathrm{Sr} /{ }^{86} \mathrm{Sr}$ of 0.70919 for the air-fall pumice compared to our value of 0.70842 . This either indicates that the volume erupted from the Long Valley magma chamber to form the air-fall pumice was not homogeneous, or that the air-fall portion of the tuff has been subject to post-eruption alteration.

\section{Characteristics of white-cored pumice}

The single fiamme from BT-22 has a white core and a black rim. To investigate what chemical and isotopic effect the process that led to the white core had, a white core and black rim glass were analyzed separately. The concentrations of $\mathrm{K}, \mathrm{Sm}$ and $\mathrm{Nd}$ are virtually identical between the core and rim (see Table 1). In contrast, the concentration of $\mathrm{Sr}$ is higher in the core than in the rim by $9 \mathrm{ppm}(46 \%)$ while $\mathrm{Rb}$ is lower in the core than the rim by $10 \mathrm{ppm}(7.6 \%)$. Assuming that the fiamme was once homogeneous, the core has gained $\mathrm{Sr}$ and lost $\mathrm{Rb}$ or the rim has lost $\mathrm{Sr}$ and gained $\mathrm{Rb}$.

Assuming that the fiamme was originally homogeneous, there has been a chemical exchange between the core and the rim of the fiamme BT-22, indicated by the differences in concentration of $\mathrm{Rb}$ and $\mathrm{Sr}$ and by the color difference between core and rim. This transfer is not evident in the major element $\mathrm{K}$ or in the traditionally immobile trace elements $\mathrm{Sm}$ and $\mathrm{Nd}$. White-cored pumice/fiamme can be found in the densely welded vitrophyre, partially welded and unwelded portions of the Bishop Tuff. They are not found in vapor phase-altered zones, presumably because they were completely erased by the alteration. That both white-cored pumice and white-cored fiamme can be found indicates that the process that formed them occurred prior to the final welding of the tuff. The age-corrected ${ }^{87} \mathrm{Sr} /{ }^{86} \mathrm{Sr}$ ratio of the core and rim glass of BT-22 are identical at the time of eruption. This, together with the chemical and isotopic homogeneity of the lower BT vitrophyre, indicates that the observed differences between feldspar and glass of the welded portion of the tuff is an original character and not a product of post-emplacement alteration.

\section{Summary}

The most reliable samples for the $\mathrm{Sr}$ initial isotopic composition of the glass and feldspar are BT-24, 29, 39, 22, and 27 and B-73. They demonstrate that there is a difference in ${ }^{87} \mathrm{Sr} /{ }^{86} \mathrm{Sr}$ initial ratio between lower BT vitrophyre and upper BT vitrophyre of $8 \times 10^{-4}$. In addition these samples exhibit $\mathrm{Sr}$ isotopic differences at the time of eruption between feldspars, glass, and biotite, the feldspar recording the isotopic composition of the magma at some time prior to eruption. The variation and differences must be attributable to processes that operated within the Bishop Tuff magma chamber rather than to post- or syn-eruptive alteration.

\section{Discussion}

For all samples measured, the ${ }^{87} \mathrm{Sr} /{ }^{86} \mathrm{Sr}$ initial ratio of the glass is higher than the associated sanidine and plagioclase phenocrysts. This indicates that the ${ }^{87} \mathrm{Sr} /{ }^{86} \mathrm{Sr}$ ratio of the magma was increasing in the magma chamber, prior to eruption, at a rate that was too fast for diffusive equilibration between the crystal and the liquid to keep pace. The ${ }^{87} \mathrm{Sr} /{ }^{86} \mathrm{Sr}$ ratio in the magma can increase because of assimilation of high ${ }^{87} \mathrm{Sr} /{ }^{86} \mathrm{Sr}$ wall-rock material, because of decay of ${ }^{87} \mathrm{Rb}$, or because of addition of new magma of a different isotopic composition.

The estimated rates of magmatic processes are limited by the time scale of equilibration of the phenocrysts with the liquid; which is primarily determined by the size of the feldspar crystals and the diffusion coefficient of $\mathrm{Sr}$ in the feldspar. The diffusivity of $\mathrm{Sr}$ in orthoclase varies from 
about $10^{-17} \mathrm{~cm}^{2} / \mathrm{s}$ at $725^{\circ} \mathrm{C}$ to about $10^{-16} \mathrm{~cm}^{2} / \mathrm{s}$ at $790^{\circ} \mathrm{C}$ (Giletti 1991; Watson and Cherniak 1991). For the $\mathrm{Fe}$-Ti oxide temperature of the lower BT $\left(725^{\circ} \mathrm{C}\right)$, using a model of a spherical grain, we calculate the time scale for equilibration of the approximately $2 \mathrm{~mm}$ diameter feldspar phenocrysts to be about $2.2 \mathrm{My}$ (see Appendix 1). This represents the time necessary for a $2 \mathrm{~mm}$ diameter grain to lose $70 \%$ of the isotopic difference between it and the surrounding magma (Appendix 1, Fig. A1). About $30 \%$ of the difference is lost in $0.265 \mathrm{My}$. A value for maximum residence time of the Bishop Tuff magma is obtained from the observations of Halliday et al. (1989). The magma erupted from the chamber at $0.74 \mathrm{Ma}$ could not have been there longer than $0.5 \mathrm{My}$, because all of the magma erupted before about $1.2 \mathrm{Ma}$ had a different $\mathrm{Nd}$ isotopic composition. On a $0.5 \mathrm{My}$ time scale, $2 \mathrm{~mm}$ feldspar grains are highly resistant to diffusive equilibration with their surroundings at the magmatic temperature of the Bishop tuff.

Because the differences in ${ }^{87} \mathrm{Sr} /{ }^{86} \mathrm{Sr}$ between the glass and phenocryst phases are small, it is convenient to define a small unit of ${ }^{87} \mathrm{Sr} /{ }^{86} \mathrm{Sr}$ :

$\Delta \mathrm{Sr}=0.00001$.

One unit of $\triangle \mathrm{Sr}$ is equal to 1 unit in the fifth decimal place of ${ }^{87} \mathrm{Sr} /{ }^{86} \mathrm{Sr}$. The lower BT glass has ${ }^{87} \mathrm{Sr} /{ }^{86} \mathrm{Sr}$ that is higher by $85 \Delta \mathrm{Sr}$ units (hereafter just "units") than that of the feldspars of the middle and upper $\mathrm{BT}$, and higher by 30 units than its associated sanidine. Therefore, to account for the isotopic difference between feldspar and glass, the rate of change of ${ }^{87} \mathrm{Sr} /{ }^{86} \mathrm{Sr}$ in the lower BT magma need only have been faster than about 30 per $2.65 \mathrm{My}$ or 11 $\mathrm{My}^{-1}$.

To further evaluate the implications of the data we use a model for the BT magma system as depicted in Fig. 4. The Long Valley system prior to eruption of the BT was layered and ultimately driven by an influx of basaltic magma deep in the crust. Each layer is fed by differentiation of the underlying layer, and differentiates to feed the next overlying layer. We further assume that this fractionation occurs by a sidewall crystallization-type mechanism, which produces a fractionated liquid of the composition of the next overlying layer, which rises along the walls and collects as the next higher magma layer. If the ${ }^{87} \mathrm{Sr} /{ }^{86} \mathrm{Sr}$ of each layer is also being affected by small amounts of assimilation of wall-rock and by radioactive decay of $\mathrm{Rb}$, the shift in ${ }^{87} \mathrm{Sr} /{ }^{86} \mathrm{Sr}\left(\mathrm{R}_{\mathrm{i}}\right)$ in magma layer $i$ with time $(t)$ is given by:

$\frac{d R_{i}}{d t}=\frac{M_{a i}}{M_{i}} \frac{C_{a}}{C_{i}}\left(R_{a}-R_{i}\right)+\frac{M_{r i}}{M_{i}} \frac{C_{i-1}}{C_{i}}\left(R_{i-1}-R_{i}\right)+\lambda \frac{{ }^{87} \mathrm{Rb}}{{ }^{86} \mathrm{Sr}_{i}}$

where $R_{a}$ and $R_{i-1}$ are the ${ }^{87} \mathrm{Sr} /{ }^{86} \mathrm{Sr}$ ratios of assimilated material and the differentiated magma being supplied from the adjacent lower layer of the chamber, respectively. $M_{a i}$ is the rate of addition of assimilated material to the $i$ th layer, $M_{r i}$ is the rate of addition of new magma $(r)$ to the layer, and $M_{i}$ is the mass of the layer. Similarly, $C_{a}, C_{i-1}$, and $C_{i}$ are the concentrations of $\mathrm{Sr}$ in assimilant, new magma and in the magma layer as a whole.

We assume that the magma layer which was the eruptive source of the lower BT $(L)$ was derived by fractional crystallization of a magma layer with the characteristics of

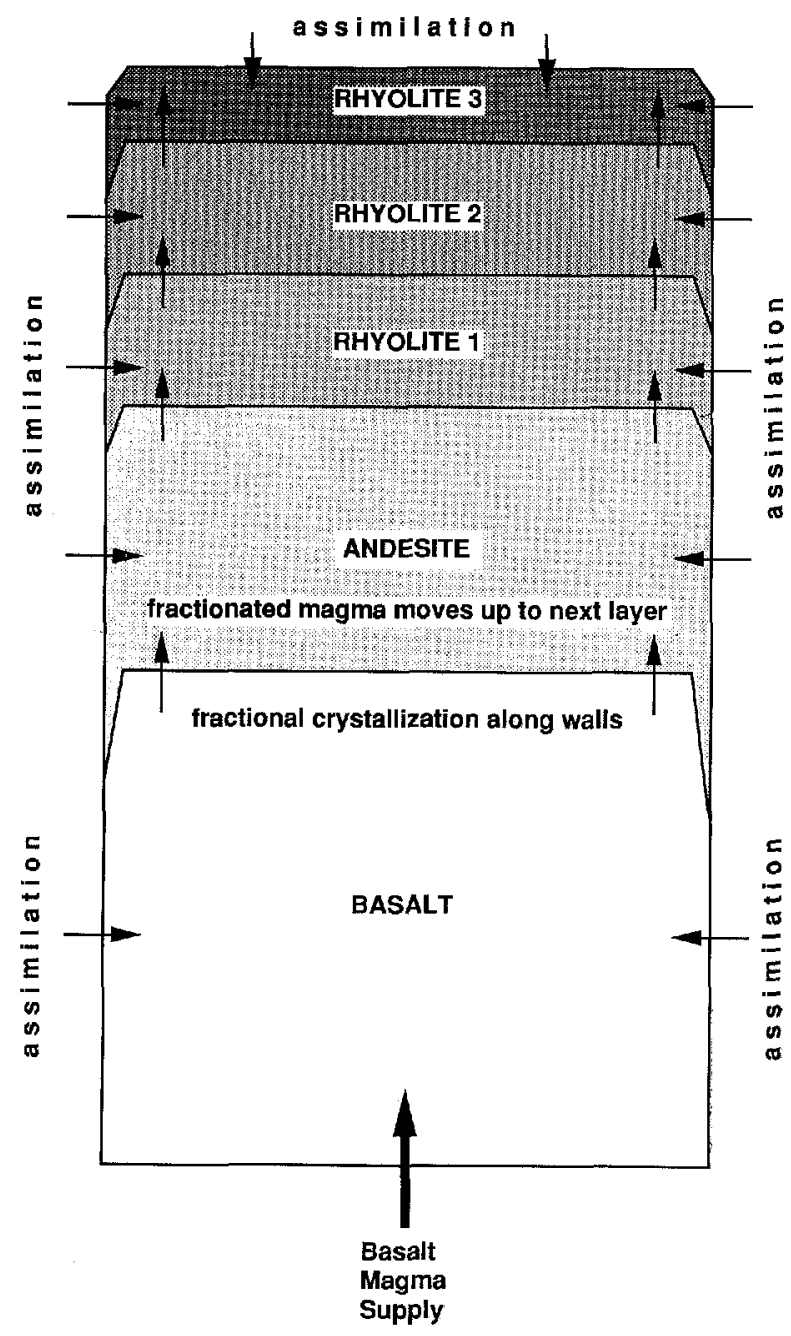

Fig. 4. Model of Long Valley magma chamber. Basaltic magma is supplied to the bottom of the system and differentiates through a sidewall fractionation process. Differentiated magma moves up along the chamber wall to feed the growing overlying layer. Similarly, the overlying layers feed successively overlying layers to produce a zoned or layered system with high silica rhyolite at the top of the chamber and less silicic magma at lower levels

the middle BT $(M)$ (Michael 1983, Cameron 1984; Christensen 1987). First we consider the isotopic evolution in the absence of any assimilation. If we assume that the mass of the lower BT magma grew at a constant rate, which is equivalent to setting $M_{L}=M_{r} t$, we obtain:

$\frac{d R_{L}}{d t}=\frac{1 C_{r}}{t C_{L}}\left(R_{M}-R_{L}\right)+\lambda \frac{{ }^{87} \mathrm{Rb}}{{ }^{86} \mathrm{Sr}_{L}}$

which for constant $R_{M}$, and ${ }^{87} \mathrm{Rb} /{ }^{86} \mathrm{Sr}$ has the particular solution:

$\left(R_{L}-R_{M}\right)=\frac{1}{2} \lambda t \frac{{ }^{87} \mathrm{Rb}}{{ }^{86} \mathrm{Sr}_{r}}$

or

$\frac{d R_{L}}{d t}=\frac{1}{2} \lambda \frac{{ }^{87} \mathrm{Rb}}{{ }^{86} \mathrm{Sr}_{L}}$.

Using $\left({ }^{87} \mathrm{Rb} /{ }^{86} \mathrm{Sr}_{L}\right)=215$ (calculated whole-rock value), the rate of increase of ${ }^{87} \mathrm{Sr} /{ }^{86} \mathrm{Sr}$ is $153 \mathrm{My}^{-1}$. This is fast 
enough to expect that the crystals would lag behind the melt in ${ }^{87} \mathrm{Sr} /{ }^{86} \mathrm{Sr}$ during its evolution. The model predicts that the isotopic difference after $0.5 \mathrm{My}$ between the lower and middle BT would be 76 units, which is exactly the observed difference at the time of the eruption. Because the $\mathrm{Rb} / \mathrm{Sr}$ of the liquid will be increasing as phenocrysts grow, this is a minimum growth rate for the liquid, whose ${ }^{87} \mathrm{Rb} /{ }^{86} \mathrm{Sr}$ is measured to be 275 . Overall, however, this model is reasonably consistent with the data.

The assimilation term in Eq. 1 can be evaluated using estimates of the isotopic composition of the granitic wall rocks, which are the local plutons of the Mesozoic Sierra Nevada batholith (Kistler and Peterman 1973, 1978). From available data we estimate that $C_{a}=500 \mathrm{ppm}$ and $\left(R_{a}-R_{m}\right)=+300 \Delta \mathrm{Sr}$ units. Therefore, using $C_{m}=2$ ppm gives a value of $\left(C_{a} / C_{m}\right)\left(R_{a}-R_{m}\right)=75000$. Any value of $M_{a} / M_{m}>0.001$ provides a significant further increment in the rate of ${ }^{87} \mathrm{Sr} /{ }^{86} \mathrm{Sr}$ growth.

Higher assimilation rates would tend to shrink the calculated time scale of magmatic processes. For example, for $M_{a} / M_{m}=0.1$, the increase in ${ }^{87} \mathrm{Sr} /{ }^{86} \mathrm{Sr}$ of 85 units in the lower BT glass in comparison to the middle BT feldspars, could be accomplished in only $12 \mathrm{ky}$. However, we also have a constraint on the rapidity with which this increase in ${ }^{87} \mathrm{Sr} /{ }^{86} \mathrm{Sr}$ took place. The constraint comes from the observation that the lower BT magma layer was homogeneous in ${ }^{87} \mathrm{Sr} /{ }^{86} \mathrm{Sr}$ at the time of eruption, so that the time for mixing of the layer by convection must be short, relative to the residence time of $\mathrm{Sr}$ in the magma layer. The residence time of $\mathrm{Sr}$ is given by:

$\tau_{\text {res }}=\frac{M_{m} C_{m}}{M_{a} C_{a}+M_{r} C_{r}}$

or

$$
\tau_{\text {res }}^{-1}=\frac{M_{a}}{M_{m}} \frac{C_{a}}{C_{m}}+\frac{M_{r}}{M_{m}} \frac{C_{r}}{C_{m}} .
$$

For the linear growth model described, the residence time decreases with time (Fig. 5). For the 0.5 My lifetime model, the residence time during the latter evolution of the system is about 0.3 to $0.5 \mathrm{My}$. For the high assimilation rate

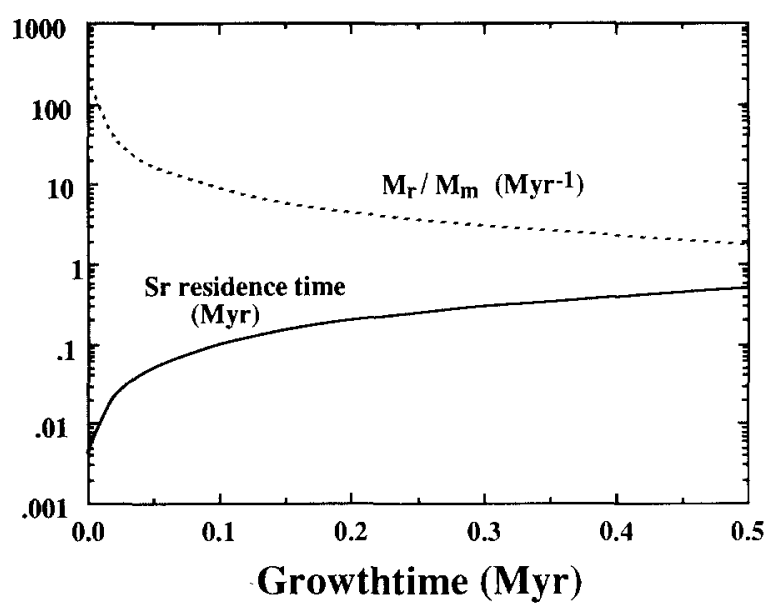

Fig. 5. Sr residence time in My plotted against the growthtime in My of a magma layer assuming a linear rate of growth. The dashed curve represents the ratio of the rate of growth of the magma layer to the mass of the magma layer
$\left(M_{a} / M_{m}=0.1\right)$, and linear growth of the magma layer in $12 \mathrm{ky}$, the limiting value for residence time of $\mathrm{Sr}$ is $\tau_{\text {res }}$ approximately equal to $12 \mathrm{ky}$.

The mixing time of a convecting layer can be estimated crudely using parameterized convection models (Kenyon and Turcotte 1987). To estimate the mixing time we use the eddy diffusivity, which is given by:

$\frac{\kappa_{\text {eddy }}}{\kappa}=1.34\left(R a / R a_{\text {crii }}\right)^{1 / 3}$,

where $R a_{\text {crit }}=1707$ and $\kappa$ is the thermal diffusivity. To obtain a Rayleigh number, we estimate that the lower BT magma layer had a thickness of $100 \mathrm{~m}$ (if the areal extent is $350 \mathrm{~km}^{2}$, then the volume would be $35 \mathrm{~km}^{3}$ ), across which a temperature difference of $20^{\circ} \mathrm{C}$ existed (roughly half the temperature difference between the typical middle unit samples and the air-fall samples). Using a kinematic viscosity range of $10^{7}$ to $10^{8} \mathrm{~cm}^{2} / \mathrm{s}$, a coefficient of expansion $(\alpha)$ of $10^{-5} \mathrm{~K}^{-1}$, and a thermal diffusivity $(\kappa)$ of $10^{-3} \mathrm{~cm}^{2} / \mathrm{s}$, we calculate a thermal $\mathrm{Ra}=2 \times 10^{6}$ to $2 \times 10^{7}$. This corresponds to $\mathrm{k}_{\text {eddy }}=1 \times 10^{-2}$ to $2 \times 10^{-2} \mathrm{~cm}^{2} / \mathrm{s}$. The characteristic diffusion distance in $10 \mathrm{ky}$ is 500 to $800 \mathrm{~m}$; in $100 \mathrm{ky}, 1.7$ to $2.5 \mathrm{~km}$. Although the reliability of this result is uncertain, we note that the characteristic eddy diffusive distance is proportional to $R a^{1 / 6}$. The deduced mixing time scale is therefore at least robust to reasonable changes in the input parameters.

This calculation suggests that mixing within a silicic magma layer with a horizontal dimension of tens of kilometers is not very efficient on these time scales. At best the mixing time that could be assigned to the lower BT layer is $100 \mathrm{ky}$, which could be sufficient to keep the layer homogeneous if the residence time of $\mathrm{Sr}$ is 300 to $500 \mathrm{ky}$ as in the linear growth model. It therefore seems highly likely that assimilation rates were not larger than about $0.001 \mathrm{My}^{-1}$ (see also Christensen 1987).

We conclude that the timespan for differentiation of the lower Bishop Tuff magma prior to eruption was about $500 \mathrm{ky}$. Most, if not all of the increase in ${ }^{87} \mathrm{Sr} /{ }^{86} \mathrm{Sr}$ is due to radioactive decay of $\mathrm{Rb}$; a small fraction could be due to assimilation. However, as discussed later, there is some evidence that assimilation rates were non-zero, albeit small, for other parts of the chamber.

The same approach can be used to understand the isotopic effects in the other portions of the magma chamber as represented by our samples. In the middle BT unit, the feldspar-glass ${ }^{87} \mathrm{Sr} /{ }^{86} \mathrm{Sr}$ difference is about ten units. Using a slightly shorter time scale for feldspar diffusive equilibration of about $2 \mathrm{My}$, reflecting the higher magma temperature, it is determined that the rate of increase of ${ }^{87} \mathrm{Sr} /{ }^{86} \mathrm{Sr}$ must be greater than $5 \mathrm{My}^{-1}$. For this unit, assuming again a linear growth model:

$\frac{1}{2} \lambda \frac{{ }^{87} \mathrm{Rb}}{{ }^{86} \mathrm{Sr}_{m}}=8 \mathrm{My}^{-1}$.

This growth rate is sufficient to account for the feldspar isotopic difference, but is insufficient to generate the observed 10 units of increase in $500 \mathrm{ky}$. For the middle BT, we estimate:

$\frac{C_{a}}{C_{m}}\left(R_{a}-R_{m}\right) \approx 6000$. 
For the middle BT it appears that a small assimilation rate of about $0.002 \mathrm{My}^{-1}$ is necessary to explain the isotopic data.

For the air-fall unit, the large difference between glass and sanidine phenocrysts requires that assimilation of radiogenic and $\mathrm{Sr}$-rich wall-rock material played a greater role than in the lower and middle BT units. For the air-fall unit,

$$
\begin{aligned}
& \frac{1}{2} \lambda \frac{{ }^{87} \mathrm{Rb}}{{ }^{86} \mathrm{Sr}_{m}} \approx 70 \mathrm{My}^{-1} \text { and } \\
& \frac{C_{u}}{C_{m}}\left(R_{u}-R_{m}\right) \approx(250)(125)=30000
\end{aligned}
$$

Therefore a value of $M_{a} / M_{m} \geq 0.02$ is required to generate 200 units of isotopic evolution in $500 \mathrm{ky}$. A higher assimilation rate would explain the higher $\mathrm{Sr}$ content of the glass and would also explain why the $\mathrm{Sr}$ concentration of the sanidine is low in comparison to the glass. Higher assimilation rates might be expected for the part of the magma chamber represented by the air-fall, which presumably was the uppermost part and most exposed to the surrounding wall-rock.

The sample with highest Fe-Ti oxide temperature (BT24) probably represents the lowermost part of the erupted segment of the BT magma chamber. It is characterized by a much larger feldspar-glass $\mathrm{Sr}$ isotopic discrepancy (55 units) than the middle BT samples. For this unit we estimate the following values for the terms in Eqs. 1 and 3:

$$
\begin{aligned}
& \frac{1}{2} \lambda \frac{{ }^{87} \mathrm{Rb}}{{ }^{86} \mathrm{Sr}_{m}}=2.6 \mathrm{My}^{-1} . \\
& \frac{C_{\mathfrak{a}}}{C_{m}}\left(R_{a}-R_{m}\right) \approx 3000 .
\end{aligned}
$$

This layer was presumably being fed by differentiation of a more mafic (andesitic) underlying layer in the chamber. We infer this because this unit terminated the eruption, and is often observed that magma is erupted down to a major compositional discontinuity in the chamber (e.g., McCurry 1985). There are two possible explanations for the upper BT data. One is a relatively higher assimilation rate $\left(M_{a} / M_{m} \approx 0.02\right)$, which would be consistent with the higher magma temperature and deeper location of this layer of the chamber. Another explanation is that the composition of the underlying source layer changed sometime prior to eruption, due to a change in composition of the ultimate basaltic parent, or due to a change in the rate of assimilation at deep crustal levels in comparison to the rate of basaltic magma supply (Perry et al. 1991). Evidence that there was a change in magma composition below the upper BT layer is provided by post-caldera sample LV-4 $(0.67 \mathrm{Ma})$ which has an ${ }^{87} \mathrm{Sr} /{ }^{86} \mathrm{Sr}$ initial ratio of 0.70661 . LV-4 may represent liquid that was present at levels of the chamber just below the maximum draw-down level of the Bishop tuff eruption. This liquid may have mixed with liquid similar to the middle BT either shortly before or during eruption. Because the feldspar of the upper BT has the same ${ }^{87} \mathrm{Sr} /{ }^{86} \mathrm{Sr}$ ratio as the feldspar of the middle BT, it is required that this deep magma was aphyric. This is not unreasonable since there are aphyric post-caldera rhyolites (Bailey ct al. 1976). Simple mixing calculations show that a mixture of $29 \%$ LV-4 liquid and $71 \%$ BT-27 liquid reproduces the $\mathrm{Sr}, \mathrm{Nd}$ and $\mathrm{Sm}$ concentrations and the $\mathrm{Sr}$ isotopic composition of the BT-24 glass.

\section{The residence time of sanidine phenocrysts of the lower BT}

We have demonstrated that the isotopic evolution of the lower BT was largely brought about by decay of ${ }^{87} \mathrm{Rb}$. It is therefore possible to use the difference in ${ }^{87} \mathrm{Sr} /{ }^{86} \mathrm{Sr}$ at eruption between lower BT feldspar and glass to estimate the average age of the phenocrysts on eruption. Consistent with the model of continuous melt accumulation, the model age of a crystal on eruption is given by:

$$
t=\frac{\left(R_{L}-R_{x t l}\right)}{\lambda\left(\frac{1}{2}\left(\frac{{ }^{87} \mathrm{Rb}}{{ }^{86} \mathrm{Sr}_{L}}\right)-\frac{{ }^{87} \mathrm{Rb}}{{ }^{86} \mathrm{Sr}_{x \ell l}}\right)}
$$

where $R_{L}$ and $R_{x t l}$ are the ${ }^{87} \mathrm{Sr} /{ }^{86} \mathrm{Sr}$ of the melt and crystal at the time of eruption. If the crystal grew instantaneously, or over a time period $\ll t$, and did not isotopically reequilibrate significantly with the melt over the time $t$, then this model age is the age of the initiation of crystal growth. If the crystal grew at a constant rate (i.e. $d m / d t=$ constant), then the model age is the average age of the crystal and the age of initiation of growth is twice the average age. The sanidine separates from the lower BT were made in a manner that strongly biased the separate towards the largest crystals, and did not represent the true crystal size distribution of the sanidine phenocrysts. The largest crystals are presumably the earliest formed crystals. Assuming a constant crystal growth rate, the model age of the lower BT sanidine separate $(190 \mathrm{ky})$ implies an age of the inception of crystal growth of 380 ky before eruption. A crystal in a melt with high $\mathrm{Rb} / \mathrm{Sr}$ will see an increasing ${ }^{87} \mathrm{Sr} /{ }^{86} \mathrm{Sr}$ as it isotopically exchanges with the melt through diffusion. For a diffusivity of $10^{-17} \mathrm{~cm}^{2} / \mathrm{s}$ and a crystal radius of $1.0 \mathrm{~mm}$, and a time scale of $10^{5}-3 \times 10^{5} \mathrm{y}$, the apparent age of crystal/liquid pair would be 75 to $80 \%$ the true age (see Appendix 1, Fig. A2). Application of this correction as an approximation of the effect of diffusive exchange on a growing crystal, gives a corrected age of $480-510 \mathrm{ky}$ (before eruption), which is approximately the time scale for the generation of the lower BT we derived from the $\mathrm{Sr}$ isotopic difference between the lower and middle BT. This crystal growth time implies that the average growth rate of the sanidine was about $10^{-14}$ $\mathrm{cm} / \mathrm{s}$. This is three to four orders of magnitude slower than crystal growth rates estimated from crystal size distributions of mafic dikes and lavas (Cashman 1990). Such a slow growth rate would indicate a very low degree of undercooling, consistent with maintenance of a low degree of crystallinity of the Bishop Tuff magma for $0.5 \mathrm{My}$. It may also reflect the higher viscosity of high silica rhyolite compared to more mafic melts.

\section{Isotopic characteristics of biotite phenocrysts}

Despite meticulous efforts to produce pure biotite separates, it appears that the best explanation of the elevated ${ }^{87} \mathrm{Sr} /{ }^{86} \mathrm{Sr}$ ratios is that a portion of the biotite is xenocrystic, even that separated from fiamme. Previously it has 
been noted that for K-Ar dating it is best to use feldspar from pumice or fiamme rather than bulk tuff in order to avoid contamination with older material (Dalrymple et al. 1965). The source of the xenocrystic biotite must have been the granitoids or metamorphic rocks of the country rock that were disrupted during the eruption of the BT. From the available data (Kistler et al. 1986; Dodge et al. 1969) such biotite is likely to have approximately $20 \mathrm{ppm}$ Sr and an ${ }^{87} \mathrm{Rb} /{ }^{86} \mathrm{Sr}$ of 140 , similar to middle BT biotite. Depending mostly on the age of the biotite (85-160 My) the xenocrystic biotite would have an ${ }^{87} \mathrm{Sr} /{ }^{86} \mathrm{Sr}$ ratio between about 0.86 and 1.02. Addition of 0.4 to $1.7 \%$ xenocrystic biotite in the biotite separates would produce the elevated ${ }^{87} \mathrm{Sr} /{ }^{86} \mathrm{Sr}$ ratios. This amounts to $12-50 \mathrm{ppm}$ xenocrystic biotite in the middle Bishop Tuff. For comparison, it has been estimated that there is only $1 \mathrm{ppm}$ xenocrystic hornblende in the tuff (Hildreth 1977, 1979). Granitic rocks in the vicinity of the caldera contain sub-equal amounts of hornblende and biotite, so the amount of xenocrystic biotite needed seems somewhat high. However, metasedimentary rocks of the Mt. Morrison roof pendant are another source of xenocrysts, and the metamorphic rocks are probably much richer in biotite than hornblende.

The biotite separate from a fiamme (BT-22) also has an elevated ${ }^{87} \mathrm{Sr} /{ }^{86} \mathrm{Sr}$ ratio, higher than a separate from a whole-rock, B-73 (see Fig. 3), making it likely that the xenocrystic biotite was introduced to the Bishop Tuff magma before eruption. Constraints on how long before eruption the xenocrysts were incorporated can be made by considering the time for diffusive exchange with the liquid. The diffusivity of $\mathrm{Sr}$ in biotite at the temperature of the BT is about $10^{-12} \mathrm{~cm}^{2} / \mathrm{s}$ based on available data (Freer 1981; Giletti 1990). Assuming a radius of $0.25 \mathrm{~mm}$, the biotite would mostly equilibrate in six years $\left(D t / a^{2}=0.3\right.$, Fig. A1) and would equilibrate to $50 \%$ of the original difference in seven months $\left(D t / a^{2}=0.03\right.$, Fig. A1). Cooling models combined with SEM studies of exsolution in feldspar indicate that there was a six month to three year pause between the eruption of the lower BT and the eruption of the middle and upper BT (Snow and Yund 1985, 1987). The eruption of the lower BT could have caused the introduction of disaggregated wall-rock to the chamber, mainly affecting the middle BT. The subsequent eruption of the middle BT 0.5 to 3 years later would be within the time frame to preserve a large portion of the isotopic character of the xenocrystic biotite. A short residence time of the xenocrystic biotite is favored in view of the observation that of the two size fractions $(<30>40$ and $<40>60$ mesh) of biotite analyzed from BT-27, the smaller size fraction has the higher ${ }^{87} \mathrm{Sr} /{ }^{86} \mathrm{Sr}$ ratio. If diffusive exchange with the liquid had been important, then the smaller size fraction would be most affected and would have a lower ${ }^{87} \mathrm{Sr} /{ }^{86} \mathrm{Sr}$ ratio. This size effect would be overridden if the xenocrystic biotite was concentrated sufficiently into the smaller size fractions.

The possibility of contamination of the feldspar separates is discounted for several reasons. Great care was taken in the creation of the BT vitrophyre sanidine separates to insure purity. Only clear, colorless euhedral grains were selected directly from the vitrophyres. Xenocrystic alkali feldspar from a 85-160 My intrusive would have a ${ }^{87} \mathrm{Sr} /{ }^{86} \mathrm{Sr}$ ratio in the approximate range of $0.7066-0.7071$. The observation that less than $1 \%$ of the biotite separate is xenocrystic implies that less than $0.1 \%$ of the BT alkali feldspar could be xenocrystic, based on the relative proportions of biotite and alkali feldspar in granite and in the BT. With a concentration of $200 \mathrm{ppm} \mathrm{Sr}$ such small amounts of xenocrystic feldspar would have a negligible effect on the feldspar from the middle and upper BT, while the more susceptible lower BT sanidine could have ratios elevated by $1-7 \times 10^{-5}$. This effect though, probably would not be observed in the analyzed sanidine separates from the lower BT because only clear, colorless euhedral grains were used for analysis. Small changes in the percentage of any xenocrystic feldspar present would have a marked effect on the ${ }^{87} \mathrm{Sr} /{ }^{86} \mathrm{Sr}$ ratio of the separate as in the case of the middle BT biotite. The remarkable agreement between the two separates of lower BT sanidine is further evidence that contamination by xenocrystic feldspar was unimportant or was eliminated by the mineral separation techniques used. In any case, xenocrystic feldspar would not help to explain the feldspar-glass isotopic difference, because xenocrystic feldspar would increase the ${ }^{87} \mathrm{Sr} /{ }^{86} \mathrm{Sr}$ of the feldspar separates and thus decrease the difference in ${ }^{87} \mathrm{Sr} /{ }^{86} \mathrm{Sr}$ between feldspar and glass.

\section{Implications of the deduced time scales}

Two issues raised by our results are (1) the maintenance of a low degree of crystallinity for long time periods (Sparks et al. 1990), and (2) the lack of any evidence for any crystal settling (Hildreth 1979), which appears inconsistent with the long residence time of crystals in the magma chamber.

The Sr isotopic data from the Bishop Tuff and the calculations made based on that data indicate that the time scale for generation of layering in the Long Valley system is about $500 \mathrm{ky}$ and that the Bishop Tuff magma maintained a low degree of crystallinity (about $10 \%$ average) for this time period. This requires that cooling of the main portion of the chamber was small during that period. The current heat loss rate for Long Valley caldera is estimated to be $2.9 \times 10^{8} \mathrm{~J} / \mathrm{s}$ (Sorey et al. 1978). In order to keep the system from crystallizing, it is necessary to add heat at this rate. Heat loss through the chamber walls can be balanced by heat from basaltic magma in the deeper portion of the system (Lachenbruch et al. 1976; Hildreth 1981; Bacon et al. 1981). The heat supply from addition of basaltic liquid to the base of the system is equal to:

$Q=M_{r} c \Delta T+M_{c} \Delta H_{c}$

Where $M_{r}$ is the rate of magma supply, $\Delta T$ is the difference in temperature between the new magma and that already in the chamber, $M_{c}$ is the rate of crystallization in the deeper parts of the system, and $\Delta H_{c}$ is the average latent heat of crystallization of the minerals crystallizing.

In order to produce $700 \mathrm{~km}^{3}$ of rhyolite in $500 \mathrm{ky}$, basalt must enter the system at a rate of at least $7000 \mathrm{~km}^{3} / \mathrm{My}$. Assuming $\Delta T=200^{\circ} \mathrm{C}, \Delta H_{\mathrm{c}}=100 \mathrm{cal} / \mathrm{g}$, $c=0.3 \mathrm{cal} / \mathrm{g}{ }^{\circ} \mathrm{C}$ and $M_{c}=0.5 M_{r}$, we calculate that the rate of heat addition to the system is $6.7 \times 10^{7} \mathrm{cal} / \mathrm{s}$ or $2.8 \times 10^{8} \mathrm{~J} / \mathrm{s}$ (see also Lachenbruch et al. 1976). Thus, we 
see no problem with maintaining the system at a nearly constant temperature for $500 \mathrm{ky}$.

With regard to the crystal settling problem, this conflict can be resolved if the Bishop Tuff magma had a finite yield strength (Bingham fluid) instead of behaving as a Newtonian fluid as assumed in Stoke's law. The Stoke's law settling velocity of a sanidine sphere with a $1.5 \mathrm{~mm}$ radius is $620 \mathrm{~m} / 10^{5} \mathrm{y}$ (for $\Delta \rho=0.4 \mathrm{~g} / \mathrm{cm}^{3}, v=10^{8} \mathrm{~cm}^{2} / \mathrm{s}$ ). The shear stress over the sanidine sphere would be 20 dynes $/ \mathrm{cm}^{2} \quad$ [shear stress $=\rho g \Delta \rho / 3 \quad$ (Maaloe 1985) $\left.r=1.5 \mathrm{~mm}, \Delta \rho=0.4 \mathrm{~g} / \mathrm{cm}^{3}\right]$ which is less than the probable yield strength of a rhyolite at temperatures below its liquidus, (by analogy with andesite, Williams and McBirney 1979). Alternatively, if the magma was convecting in a series of layers, crystals could have been retained within the convection cells (Marsh and Maxey 1985). During the $500 \mathrm{ky}$ period that the middle and lower BT were separated there must have been no convective mixing over that portion of the magma chamber in order to preserve the layering (Christensen and DePaolo 1987; Christensen 1987). A similar conclusion has been reached in the case of the Grizzly Peak Tuff (Johnson and Fridrich 1990).

The creation of $700 \mathrm{~km}^{3}$ of magma in $500 \mathrm{ky}$ indicates that fractionated magma accumulated at a rate of $1.4 \times 10^{-3} \mathrm{~km}^{3} / \mathrm{y}$. This compares well with estimates made from plots (first suggested by Smith 1979) of eruptive volume versus repose time which indicate a magma generation rate of $\sim 10^{-3} \mathrm{~km}^{3} / \mathrm{y}$ for a wide range of system size (Spera and Crisp 1981; Trial and Spera 1990). Wolff et al. 1990 estimated a minimum time scale of the order $10^{5} \mathrm{y}$ for the production of the Bishop Tuff magma. Their estimate is based on approximate equations describing the rate of production of magma in a sidewall fractionation process (Nilson et al. 1985; Thompson and Szekely 1989). The consistency of the time scales we have calculated from our observations with those predicted by Wolff et al. (1990), lend support to models of sidewall crystallization for the generation of large volumes of silicic magma.

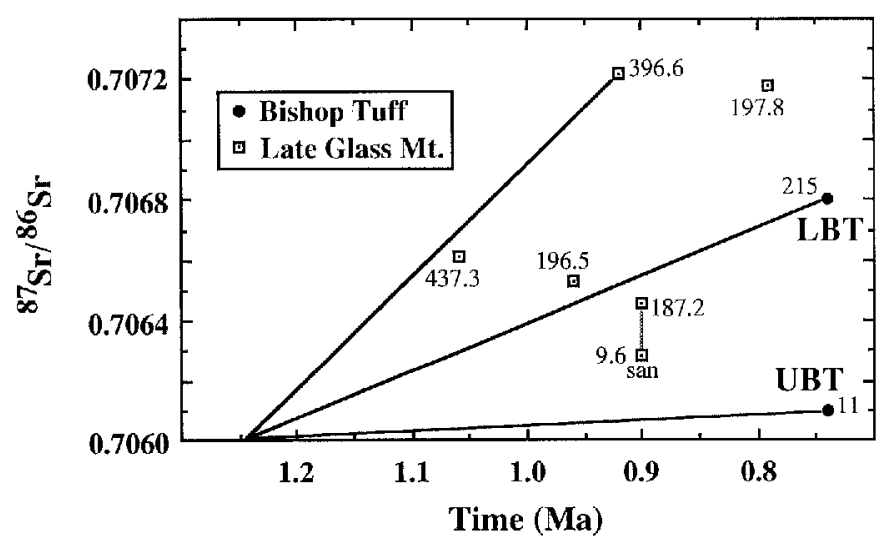

Fig. 6. Plot of ${ }^{87} \mathrm{Sr} /{ }^{86} \mathrm{Sr}$ versus time. Slopes of evolution lines are proportional to $1 / 2\left({ }^{87} \mathrm{Rb} /{ }^{86} \mathrm{Sr}\right)$. Squares are initial ratios of late Glass Mt. whole-rock samples plotted against their eruption age (data from Halliday et al. 1989). Closed circles are lower Bishop Tuff (LBT) and upper Bishop Tuff (UBT). Numbers by symbols are ${ }^{87} \mathrm{Rb} /{ }^{86} \mathrm{Sr}$
Halliday et al. (1989) in their Sr isotopic study of Glass Mountain concluded that Glass Mountain lavas younger than 1.2 My had a long residence time in the chamber $\left(4 \times 10^{5} \mathrm{y}\right)$ but that they were generated in less than $10^{4} \mathrm{y}$ at about $1.2 \mathrm{My}$. At a rate of $10^{-3} \mathrm{~km}^{3} / \mathrm{y}$ the volume of this later portion of the Glass Mountain sequence, $7 \mathrm{~km}^{3}$ (Metz and Mahood 1988), could be generated in $7 \mathrm{ky}$. However, the $\mathrm{Sr}$ isotopic data of their Late Glass Mt. samples are also compatible with our model of a growing differentiating magmatic system. The initial ${ }^{87} \mathrm{Sr} /{ }^{86} \mathrm{Sr}$ of those Glass Mt. samples that have ${ }^{87} \mathrm{Rb} /{ }^{86} \mathrm{Sr}$ similar to the lower Bishop Tuff (about 200) fall close to our model evolution curve for the lower Bishop Tuff (Fig. 6). The two Late Glass Mt. samples with ${ }^{87} \mathrm{Rb} /{ }^{86} \mathrm{Sr}$ of about 400 also fall on an evolution line that is consistent with an initiation age of approximately 1.2 Ma (Fig. 6). Thus our model predicts that the $\mathrm{Rb}-\mathrm{Sr}$ data on samples from the chamber will form a pseudo-isochron with approximately the amount of scatter observed by Halliday et al. (1989). The "isochron" age of $1.14 \pm 0.08$ Ma determined by Halliday et al. (1989) represents an approximate mean age of differentiation of the chemically distinct layers in the system, as they were sampled between 1.06 and $0.79 \mathrm{Ma}$.

\section{Summary}

Samples of Bishop Tuff (BT) fiamme and pumice were carefully chosen and separates of glass and minerals made in such a way as to avoid problems of lithic contamination and post-eruption alteration. All samples analyzed exhibit $\mathrm{Sr}$ isotopic differences between feldspar and glass at the time of the eruption, $0.74 \mathrm{Ma}$. The vitrophyre samples demonstrate a pre-eruption variation in ${ }^{87} \mathrm{Sr} /{ }^{86} \mathrm{Sr}$ between upper and lower BT of 0.70600 to 0.70685 . Samples of tuff with similar $\mathrm{Fe}-\mathrm{Ti}$ oxide temperatures from widely separated locations have nearly identical isotopic properties for both glass and phenocrysts. These results indicate that the magma chamber was fillcd with chemically and isotopically distinct layers of magma, each of which was internally homogeneous.

The isotopic distinction between phenocrysts and glass gives a minimum rate of change of the ${ }^{87} \mathrm{Sr} /{ }^{86} \mathrm{Sr}$ ratio in the magma and thus a minimum rate of evolution of the differentiated layers of magma. The observation of homogeneity in the layers, on the other hand, gives a maximum rate of isotopic evolution. These two considerations indicate that the time scale for development of the compositional layers and their isotopic properties is about 500 ky. This model is depicted in Fig. 7. In the lower BT unit, radioactive decay of $\mathrm{Rb}$ is the primary cause of the increasing ${ }^{87} \mathrm{Sr} /{ }^{86} \mathrm{Sr}$ ratio in the magma. In the uppermost and lowermost units of the tuff, those characterized by the lowest and highest apparent temperatures, there is the greatest isotopic difference between glass and phenocrysts; this observation is interpreted to be due to higher assimilation rates.

Biotite phenocrysts in the middle BT unit have particularly high and discrepant ${ }^{87} \mathrm{Sr} /{ }^{86} \mathrm{Sr}$ ratios relative to associated glass and feldspar phenocrysts. A small fraction of the biotite must therefore be xenocrystic, and was probably introduced to the magma during eruption. The 


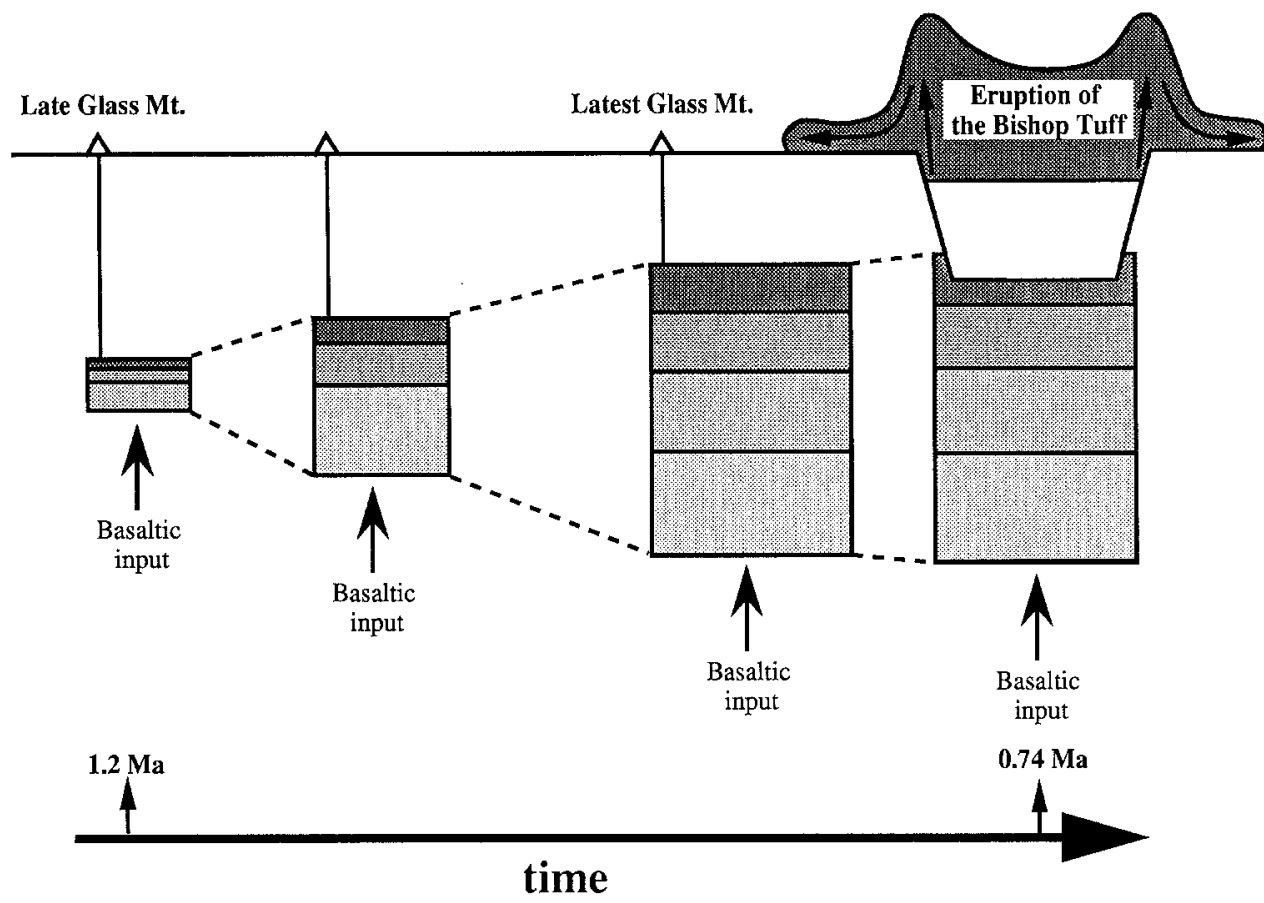

Fig. 7. A schematic representation of the evolution of the long Valley magmatic system between about $1.2 \mathrm{Ma}$ and the eruption of the Bishop Tuff at $0.74 \mathrm{Ma}$ long period of isolation of these magma batches implies the existence of a stratified, density-stabilized convection system in the chamber. There appears to be little evidence for mixing among the layers on eruption.

\section{Appendix 1}

\section{Diffusive exchange between crystals and liquid}

A complete mathematical model would describe the isotopic evolution of a crystal growing from and diffusively exchanging with a liquid that has an ${ }^{87} \mathrm{Sr} /{ }^{86} \mathrm{Sr}$ ratio that is a function of time. As a start toward understanding this relatively complicated situation, we consider the diffusive exchange of a sphere of fixed size with a liquid of constant but contrasting isotopic composition. Since we are interested in the ${ }^{87} \mathrm{Sr} /{ }^{86} \mathrm{Sr}$ ratio, both the diffusion of ${ }^{87} \mathrm{Sr}$ and ${ }^{86} \mathrm{Sr}$ must be considered. Separate equations for the diffusion of ${ }^{87} \mathrm{Sr}$ and ${ }^{86} \mathrm{Sr}$ can be set up using the equation for diffusion in a sphere (Crank 1975):

$$
\frac{C-C_{1}}{C_{0}-C_{1}}=1+\frac{2 a}{\pi r} \sum_{n=1}^{\infty} \frac{(-1)^{n}}{n} \sin \left(\frac{n \pi r}{a}\right) \exp \left(\frac{-n^{2} \pi^{2} D t}{a^{2}}\right)
$$

where $C_{1}$ refers to the initial concentration within the sphere, $C_{0}$ to the concentration outside the sphere, a the radius of the sphere, $r$ the distance from the center of the sphere $(0<r<a), D$ the diffusivity for the sphere and $t$ time. Taking the ratio between the equation for ${ }^{87} \mathrm{Sr}$ and the equation for ${ }^{86} \mathrm{Sr}$, and re-arranging in a manner similar to Cygan and Lasaga (1985) yields:

$$
\begin{aligned}
& {\left[\frac{1+\left({ }^{87} \mathrm{Sr} /{ }^{86} \mathrm{Sr}\right)_{\mathrm{melt}}}{1+\left({ }^{87} \mathrm{Sr} /{ }^{86} \mathrm{Sr}\right)_{\mathrm{xt} 1}}\right] \frac{\left({ }^{87} \mathrm{Sr} /{ }^{86} \mathrm{Sr}\right)_{\mathrm{r}}-\left({ }^{87} \mathrm{Sr} /{ }^{86} \mathrm{Sr}\right)_{x t l}}{\left({ }^{87} \mathrm{Sr} /{ }^{86} \mathrm{Sr}\right)_{\mathrm{melt}}-\left({ }^{87} \mathrm{Sr} /{ }^{86} \mathrm{Sr}\right)_{x t l}}} \\
& =1+\frac{2 a}{\pi r} \sum_{n=1}^{\infty} \frac{(-1)^{n}}{n} \sin \left(\frac{n \pi r}{a}\right) \exp \left(\frac{-n^{2} \pi^{2} \mathrm{Dt}}{a^{2}}\right)
\end{aligned}
$$

The first part in brackets of the left hand term is essentially one for reasonable values of the ${ }^{87} \mathrm{Sr} /{ }^{86} \mathrm{Sr}$ of the crystal and liquid. Thus this equation reduces to:

$$
\begin{aligned}
& \frac{\left({ }^{87} \mathrm{Sr} /{ }^{86} \mathrm{Sr}\right)_{r}-\left({ }^{87} \mathrm{Sr} /{ }^{86} \mathrm{Sr}\right)_{x t l}}{\left({ }^{87} \mathrm{Sr} /{ }^{86} \mathrm{Sr}\right)_{\mathrm{melt}}-\left({ }^{87} \mathrm{Sr} /{ }^{86} \mathrm{Sr}\right)_{x t l}} \\
& =1+\frac{2 a}{\pi r} \sum_{n=1}^{\infty} \frac{(-1)^{n}}{n} \sin \left(\frac{n \pi r}{a}\right) \exp \left(\frac{-n^{2} \pi^{2} D t}{a^{2}}\right)
\end{aligned}
$$

The average value of the isotopic difference for the entire spherical grain relative to the original difference between the grain and liquid is given by (adapted from Carslaw and Jaeger 1959):

$$
\frac{\left({ }^{87} \mathrm{Sr} /{ }^{86} \mathrm{Sr}\right)_{\text {ave }}-\left({ }^{87} \mathrm{Sr} /{ }^{86} \mathrm{Sr}\right)_{x t l}}{\left({ }^{87} \mathrm{Sr} /{ }^{86} \mathrm{Sr}\right)_{\text {melt }}-\left({ }^{87} \mathrm{Sr} /{ }^{86} \mathrm{Sr}\right)_{x i l}}=1-\frac{6}{\pi^{2}} \sum_{n=1}^{\infty} \frac{1}{n^{2}} \exp \left(\frac{-n^{2} \pi^{2} \mathrm{Dt}}{a^{2}}\right)
$$

This is plotted in Fig. A1 versus $D t / a^{2}$. With a diffusivity of $10^{-16} \mathrm{~cm}^{2} / \mathrm{s}$ and a $2 \mathrm{~mm}$ diameter grain, the original difference is reduced by $50 \%$ in $0.1 \mathrm{My}$. Increasing the diameter of the grain reduces the effect of diffusion.

A further step in complexity is to consider a crystal diffusively exchanging with a melt with increasing ${ }^{87} \mathrm{Sr} /{ }^{86} \mathrm{Sr}$. If the melt is increasing its ${ }^{87} \mathrm{Sr} /{ }^{86} \mathrm{Sr}$ linearly, as would be the case for a melt with a constant $\mathrm{Rb} / \mathrm{Sr}$ ratio, the average isotopic composition of the crystal is given by (after Crank 1975):

$$
\begin{aligned}
\left({ }^{87} \mathrm{Sr} /{ }^{86} \mathrm{Sr}\right)_{x t l . \text { ave. }}= & \left({ }^{87} \mathrm{Sr} /{ }^{86} \mathrm{Sr}\right)_{x t l . \text { init. }}+k\left(t-\frac{a^{2}}{{ }^{15} D}\right) \\
& +\frac{6 a^{2}}{\pi^{4} D} \sum_{n=1}^{\infty} \frac{1}{n^{4}} \mathrm{e}^{-n^{2} \pi^{2} D t / a^{2}}
\end{aligned}
$$

where $k$ is rate of ${ }^{87} \mathrm{Sr} /{ }^{86} \mathrm{Sr}$ change of the melt, which in the linear magma layer growth model without assimilation is equal to $1 / 2 \lambda^{87} \mathrm{Rb}^{86} \mathrm{Sr}_{m}$. The other symbols are as in Eq. A1. Equation A5 was used to create Fig. A2, which shows the relationship between the percentage of the true age of a melt/crystal pair and $D / a^{2} / k$

The effects calculated for diffusive exchange in the Bishop tuff sanidine separates actually analyzed would be reduced for two reasons. One factor is that the average size of the feldspar crystals from the Bishop tuff is probably larger than $2 \mathrm{~mm}$, the size assumed in the demonstration calculations (Fig. A1). This is especially true for the lower BT vitrophyre sanidine separates which were made by hand picking 


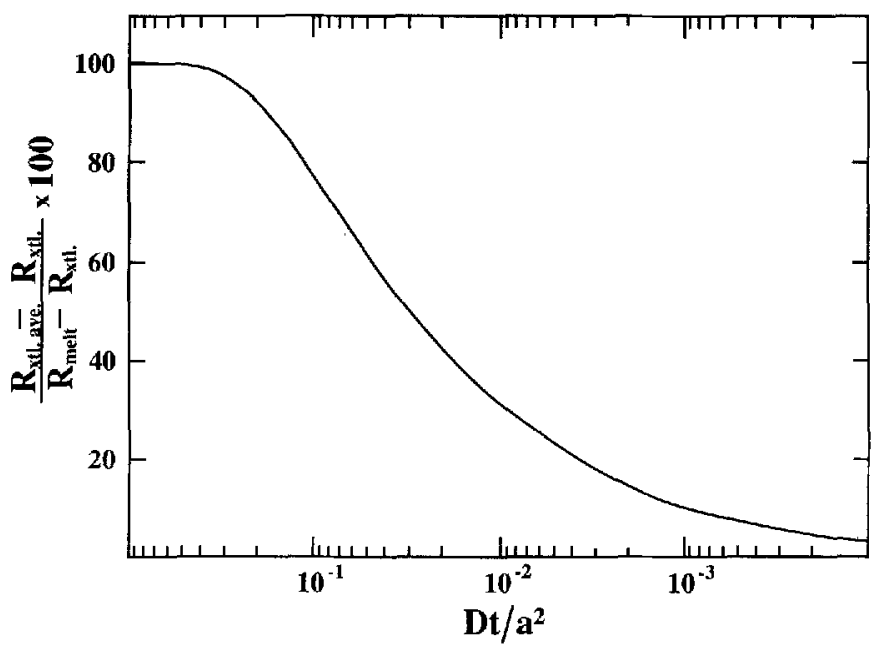

Fig. A1. The difference between ${ }^{87} \mathrm{Sr} /{ }^{86} \mathrm{Sr}$ of a crystal averaged over its volume $\left(R_{x t i . a v e}\right)$ and its original ${ }^{87} \mathrm{Sr} /{ }^{86} \mathrm{Sr}\left(R_{x t l}\right)$ divided by the difference between ${ }^{87} \mathrm{Sr} /{ }^{86} \mathrm{Sr}$ of the melt $\left(R_{m e l l}\right)$ and $R_{x z l}$ versus $D t / a^{2}$, where $D$ is the diffusivity of $\mathrm{Sr}$ in the crystal, $t$ is time and $a$ is the crystal radius. This is for a model in which a spherical crystal diflusively exchanges with a melt of contrasting isotopic composition. A value of 100 on the $y$-axis indicates complete equilibration of the crystal with the melt

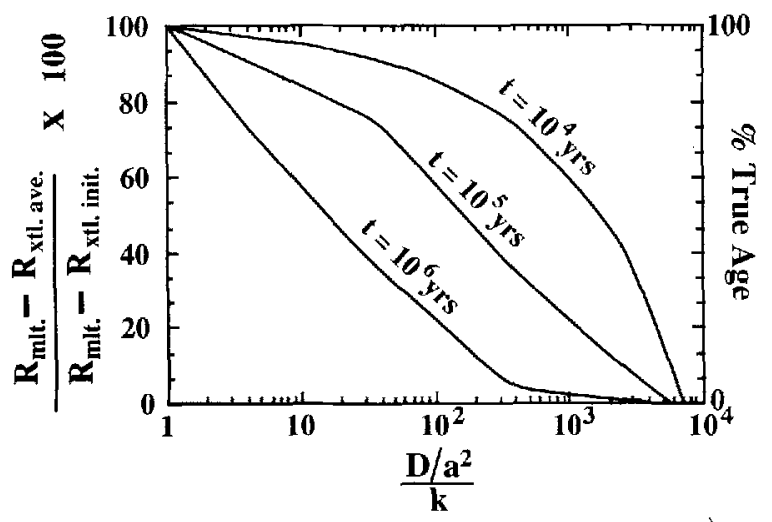

Fig. A2. The difference between ${ }^{87} \mathrm{Sr} /{ }^{86} \mathrm{Sr}$ of a melt $\left(R_{m l t}\right)$ and ${ }^{87} \mathrm{Sr} /{ }^{86} \mathrm{Sr}$ of a crystal averaged over its volume $\left(\mathrm{R}_{x+l .}\right)$ divided by the difference between $\mathrm{R}_{m l t}$ and the initial ${ }^{87} \mathrm{Sr} /{ }^{86} \mathrm{Sr}$ of the crystal $\left(\mathrm{R}_{x t l \text {. init }}\right)$ versus $D / a^{2} / k$, where $D$ is the diffusivity of $\mathrm{Sr}$ in the crystal, $a$ is the crystal radius and $k$ is the rate of change the melt ${ }^{87} \mathrm{Sr} /{ }^{86} \mathrm{Sr}$. This plot is for a model in which a spherical crystal is diffusively exchanging with a melt of increasing ${ }^{87} \mathrm{Sr} /{ }^{86} \mathrm{Sr}$. Initially the crystal and the melt have the same ${ }^{87} \mathrm{Sr} /{ }^{86} \mathrm{Sr}$. The curves are for different apparent ages (0.01 My, $0.1 \mathrm{My}$ and $1.0 \mathrm{My})$ of the melt/crystal pair. The right hand $y$-axis gives the percentage of the true age of the melt/crystal pair

\section{Appendix 2}

\section{Sample localities and descriptions}

$B T-24$. White cored pumice extracted from partially welded tuff; $\mathrm{Fe}-\mathrm{Ti}$ oxide temperature approximately $790^{\circ} \mathrm{C}$ (Hildreth 1977). Collected near the top of Aeolian Buttes, about $15 \mathrm{~m}$ below locality B-77 of Hildreth (1977). Phenocrysts, in order of decreasing abundance: sanidine, quartz and plagioclase. Minor quantities of biotite, clinopyroxene, orthopyroxene and $\mathrm{Fe}-\mathrm{Ti}$ oxides.

$B T-27$. Black, glassy vitrophyre; Fe-Ti oxide temperature approximately $760^{\circ} \mathrm{C}$ (Hildreth 1977); from the base of Aeolian Buttes, sample locality B-79 of Hildreth (1977). Densely welded, glassy, with little or no evidence of hydration. Contains sanidine, quartz and plagioclase with minor amounts of biotite, orthopyroxene, clinopyroxene and Fe-Ti oxides.

$B T-22$. Vitrophyre from roadcut on .US Route 395,5 miles south of Aeolian Buttes. Probable temperature was $760^{\circ} \mathrm{C}$ based on stratigraphic position. Many fiamme have white cores and black rims. Contains sanidine, quartz, plagioclase and minor amounts of biotite, clinopyroxene, orthopyroxene and $\mathrm{Fe}-\mathrm{Ti}$ oxides.

$B T-39$. Densely welded vitrophyre from bottom of Rock Creek gorge (locality B-81 of Hildreth 1977). Fe-Ti oxide temperature $727^{\circ} \mathrm{C}$ (Hildreth 1977). Quartz, sanidine and plagioclase with minor amounts of biotite and $\mathrm{Fe}-\mathrm{Ti}$ oxide and trace quantities of allanite. Fiamme and crystals in a matrix of glass shards. Shards are outlined by glass dust.

$B T-29$. Densely welded vitrophyre from canyon of San Joaquin river, near Devil's Postpile (also known as tuff of Reds Meadow), locality B-129 of Hildreth (1977). Fe-Ti oxide temperature $713^{\circ} \mathrm{C}$ (Hildreth 1977). Fiamme and crystals (as in BT-39) in a matrix of welded glass shards outlined by glass dust. Smaller average shard size than BT-39 and more glass dust in matrix.

$B T-7$. Pumice from the basal unwelded portion of the ash flow, from the southern escarpment of the tableland, north of Bishop, locality B-20 of Hildreth 1977. Fe-Ti oxide temperature approximately $725^{\circ} \mathrm{C}$ (Hildreth 1977). Contains quartz, sanidine, plagioclase and biotite. Trace amounts of cpx and opx were found in heavy mineral concentrates.

$B T-6$. Pumice from air-fall unit, unwelded. Same locality as BT-7 but from $3 \mathrm{~m}$ below, roughly equivalent to B-82, Hildreth 1977. Fe-Ti oxide temperature of $722^{\circ} \mathrm{C}$ (Hildreth 1977). Contains quartz, sanidine, plagioclase and biotite.

$L V$-10. Post-Bishop Tuff alkali basalt, within the caldera near Mammoth turn off from Route 395. K-Ar age of 0.06 My (Bailey 1976, locality no. 23).

$L V-4$. Post-Bishop Tuff rhyolite from hill 7981 within resurgent dome, near Bailey et al. (1976) locality no. 3 with K-Ar age of $0.68 \mathrm{My}$ (corrected age using new decay constant, Mankinen et al. 1986). A porphyritic obsidian, with phenocrysts of plagioclase with lesser amounts of orthopyroxene and trace amounts of biotite and oxides.

$O A B$-1. Pre-Bishop Tuff alkali basalt, just outside caldera in roadcut of Route 395 just north of Crestview. K/Ar age of 2.9 My (Bailey et al. 1976; Mankinen et al. 1986 (locality no. 21).

Acknowledgements. JNC would like to thank Joy Crisp for her assistance in the field. Wes Hildreth provided sample B-73 that started this work, back in 1980 . This research was supported by NSF grants, EAR84-15143, EAR87-20609 and EAR90-04152.

\section{References}

Bacon RC, MacDonald R, Smith RL, Baedecker PA (1981) Pleistocene high-silica rhyolites of the Coso volcanic field, Inyo County, California. J. Gcophys Res 86:10223-10241

Bailey RA (1974) Preliminary geologic map and cross sections of the Casa Diablo geothermal area, Long Valley caldera, Mono County, California. US Geol Surv Open-File Report C74-1007 and hand picking. In the creation of the sanidine separates from the lower BT vitrophyre by hand picking directly, the inner portions of crystals were preferentially selected. from the rock sample, a process that favors larger crystals. Secondly, the diffusion, is preferentially removed during the processing of the mineral separates and may have been abraded or broken off during cruption and emplacement of the flow. Crystals or fragments of crystals with adhering emplacem 
Bailey RA, Dalrymple GB, Lanphere MA (1976) Volcanism, structure, and geochronology of Long Valley caldera, Mono County, California. J Geophys Res 81:725-744

Blake S, Ivey GN (1986) Density and viscosity gradients in zoned magma chambers, and their influence on withdrawal dynamics. J Volcanol Geotherm Res 30:201-230

Cameron KL (1984) Bishop tuff revisited: new rare earth element data consistent with crystal fractionation. Science 224: $1338-1340$

Carslaw HS, Jaeger JC (1959) Conduction of heat in solids. Oxford University Press, New York

Cashman KV (1990) Textural constraints on the kinetics of crystallization of igneous rocks. In: Nicholls J, Russell JK (eds) Modern methods of igneous petrology: understanding magmatic processes. Min Soc Am Mineral 24:259-314

Chesterman CW (1968) Volcanic history of the Bodie Hills, Mono County, California. Geol Soc Amer Mem 116:45-68

Christiansen EH (1983) The Bishop tuff revisited: compositional zonation by double-diffusive fractional crystallization (DDFC): Geol Soc Am Asbstr 15:390

Christensen JN (1987) A Strontium isotopic study of processes in a silicic magma chamber: the Bishop tuff, Long Valley, California. MS thesis, University of California, Los Angeles

Christensen JN, DePaolo DJ (1987) Isotopic study of processes in a silicic magma chamber: the Bishop tuff, Long Valley, California. EOS $68: 434$

Crank J (1975) The mathematics of diffusion, 2nd ed. Oxford University Press, New York

Cygan RT, Lasaga AC (1985) Self diffusion of magnesium in garnet at $750^{\circ} \mathrm{C}$ to $900^{\circ} \mathrm{C}$. Am J Sci $285: 328-350$

Dalrymple GB (1980) K-Ar ages of the Friant pumice member of the Turlock Lake Formation, the Bishop tuff, and the tuff of Reds Meadow, central California. Isochron/West, 28:3-5

Dalrymple GB, Cox A, Doell RR (1965) Potassium-argon age and paleomagnetism of the Bishop tuff, California. Geol Soc Amer Bull, 76:665-674

Dodge FCW, Smith VC, Mays RE (1969) Biotites from granitic rocks of the central Sierra Nevada Batholith, California. J Petrol $10: 205-271$

Freer R (1981) Diffusion in silicate minerals and glasses: a data digest and guide to the literature. Contrib Mineral Petrol $76: 440-454$

Gilbert CM (1938) Welded tuff in eastern California. Geol Soc Am Bull $49: 1829-1862$

Gilbert CM, Christiansen MN, Al-Rawi Y, Lajoie KR (1968) Structural and volcanic history of Mono Basin, California-Nevada. Geol Soc Am Mem 116:275-329

Giletti BJ (1990) Mg, Ca, $\mathrm{Sr}$ and $\mathrm{Ba}$ diffusion in plagioclase and $\mathrm{Sr}$ diffusion in micas. EOS $72: 292$

Giletti BJ (1991) Rb and Sr diffusion in feldspars, with implications for cooling histories of rocks. Geochim Cosmochim Acta $55: 1331-1343$

Halliday AN, Fallick AE, Hutchinson J, Hildreth W (1984) A Nd, Sr, and $O$ isotopic investigation into the causes of chemical and isotopic zonation in the Bishop tuff, California. Earth Planet Sci Lett $68: 379-391$

Halliday AN, Mahood GA, Holden P, Metz JM, Dempster TJ, Davidson JP (1989) Evidence for long residence times of rhyolitic magma in the Long Valley magmatic system: the isotopic record in precaldera lavas of Glass Mountain. Earth Planet Sci Lett $94: 274-290$

Hildreth EW (1977) The magma chamber of the Bishop tuff: gradients in temperature, pressure and composition. $\mathrm{PhD}$ Thesis, University of California Berkeley

Hildreth W (1979) The Bishop tuff: evidence for the origin of compositional zonation in silicic magma chambers: Geol Soc Am Spec Pap 180:43-75

Hildreth W (1981) Gradients in silicic magma chambers: implications for lithospheric magmatism: J Geophys Res, $86: 10153-10192$

Hildreth W, Mahood GA (1986) Ring fracture eruption of the Bishop tuff: Geol Soc Am Bull 97: 396-403
Huber NK, Rinehart CD (1967) Cenozoic volcanic rocks of the Devil's Postpile quadrangle, eastern Sierra Nevada, California. US Geol Surv Prof Pap 554-D:D1-D21

Hurford AJ, Hammerschmidt $\mathrm{K}(1985){ }^{40} \mathrm{Ar} /{ }^{39} \mathrm{Ar}$ and $\mathrm{K} / \mathrm{Ar}$ dating of the Bishop and Fish Canyon tuffs: calibration ages for fissiontrack dating standards. Chem Geol (Isotope Geosci) $58: 23-32$

Izett GA(1982) The Bishop ash bed and some older compositionally similar ash beds in California, Nevada and Utah. US Geol Surv, Open-File Rept no. 82-582

Johnson CM, Fridrich CJ (1990) Non-monotonic chemical and O, $\mathrm{Sr}, \mathrm{Nd}$, and $\mathrm{Pb}$ isotope zonations and heterogeneity in the maficto silicic-composition magma chamber of the Grizzly Peak tuff, Colorado. Contrib Mineral Petrol 105:677-690

Kenyon PM, Turcotte DL (1987) Along-strike magma mixing beneath mid-ocean ridges: effects on isotopic ratios: Earth Planet Sci Lett, 84 : 393-405

Kistler RW, Peterman ZE (1973) Variations in Sr, Rb, K, Na and initial ${ }^{87} \mathrm{Sr} /{ }^{86} \mathrm{Sr}$ in Mesozoic granitic rocks and intruded wall rocks in central California. Geol Soc Am Bull 84:3489-3512

Kistler RW, Peterman ZE (1978) Reconstruction of crustal blocks of California on the basis of initial strontium isotopic compositions of Mesozoic granitic rocks. US Geol Surv Prof Pap 1071

Kistler RW, Chappell BW, Peck DL, Bateman PC (1986) Isotopic variation in the Toulumme intrusive suite, central Sierra Nevada, California. Contrib Mineral Petrol 94:205-220

Koeppen RP (1983) Petrochemical evolution of Mammoth Mountain, Long Valley caldera, eastern California. EOS 64:889

Lachenbruch AH, Sass JH, Munroe RJ, Moses TH Jr (1976) Geothermal setting and simple heat conduction models for the Long Valley caldera. J Geophys Res $81: 769-784$

Maaloe S (1985) Igneous petrology. Springer Berlin New York Heidelberg Tokyo

Mankinen EA, Gromme CS, Dalrymple GB, Lanphere MA, Bailey RA (1986) Paleomagnetism and K-Ar ages of volcanic rocks from Long Valley caldera, California. J Geophys Res, 91:633-652

Marsh BD, Maxey MR (1985) On the distribution and separation of crystals in convecting magma: J Volcanol Geotherm Res $24: 95-150$

Marshall BD, DePaolo DJ (1982) Precise age determinations and petrogenetic studies using the K-Ca method: Geochim Cosmochim Acta 46:2537-2545

McCurry M (1985) The petrology of the Woods Mountains volcanic center, San Bernadino County, California. PhD Thesis, University of California Los Angeles

Metz J, Mahood GA (1985) Precursors to the Bishop tuff eruption: Glass Montain, Long Valley, California. J Geophys Res 90:11, $121-11,126$

Metz J, Mahood GA (1991) Development of the Long Valley, California, magma chamber recorded in precaldera rhyolite lavas of Glass Mountain. Contrib Mineral Petrol 106:379-397

Michael PJ (1983) Chemical differentiation of the Bishop tuff and other high-silica magmas through crystallization processes. Geology 112:31-34

Miller CD (1985) Holocene eruptions at the Inyo volcanic chain, California: implications for possible eruptions in Long Valley caldera. Geology 13:14-17

Nash WP, Crecraft HR (1985) Partition coefficients for trace elements in silicic magmas. Geochim Cosmochim Acta 49:2309-2322

Nilson RH, McBirney AR, Baker BH (1985) Liquid fractionation. Part II: fluid dynamics and quantitative implications for magmatic systems. J. Volcanol Geotherm Res, 24:25-54

Noble DC, Hedge CE $(1970){ }^{87} \mathrm{Sr} /{ }^{86} \mathrm{Sr}$ variations within individual ash-fiow sheets. US Geol Surv Prof Pap 650-c: c133-c139

Perry FV, Baldridge WS, DePaolo DJ, Shafiqullah M (1991) Evolution of a magmatic system during continental extension: the Mount Taylor volcanic field, New Mexico. Geophys Res 95: 19327-19348

Rinehart CD, Ross DC (1964) Geology and mineral deposits of the Mount Morrison quadrangle, Sierra Nevada, California. US Geol Surv Prof Pap 385 
Sheridan MF (1965) The mineralogy and petrology of the Bishop tuff: $\mathrm{Ph} \mathrm{D}$ Thesis, Stanford University, Palo Ato, California

Silberman ML, Chesterman CW (1972) K/Ar age of volcanism and mineralization Bodie Mining district and Bodie Hills volcanic field, Mono County, California. Isochron/West 3:13-22

Smith RL (1979) Ash-flow magmatism. Geol Soc Am Spec Pap 180:5-27

Snow E, Yund RA (1985) Thermal history of a Bishop tuff section as determined from the width of cryptoperthite lamellae. Geology $13: 50-53$

Snow E, Yund RA (1987) Cryptoperthites and thermal history of the Bishop tuff, revisited. EOS $68: 434$

Sorey ML, Lewis RE, Olmsted FH (1978) The hydrothermal system of Long Valley caldera, California. US Geol Surv Prof Pap 1044-A:A1-A60

Sparks RSJ, Huppert HE, Wilson CJN (1990) Discussion of "Evidence for long residence times of rhyoltic magma in the Long Valley magmatic system: the isotopic record in precaldera lavas of Glass Mountain" by AN Halliday, GA Mahood, P Holden, JM Metz, TJ Dempster and JP Davidson. Earth Planet Sci Lett, 99: 387-389

Spera FJ, Crisp JA (1981) Eruption volume, periodicity and caldera area: relationships and inferences on development of composi- tional zonation in silicic magma chambers. J Volcanol Geotherm Res 11:169-187

Thompson ME, Szekeley J (1989) Density stratification due to counterbuoyant flow along a vertical crystallization front. Int J Heat Mass Transfer 32: 1021-1036

Trial AF, Spera FJ (1990) Mechanisms for the generation of compositional heterogeneities in magma chambers. Geol Soc Am Bull, 102:353-367

Watson EB, Cherniak DJ (1991) Diffusion of strontium in K-feldspar measured by Rutherford backscattering spectroscopy. EOS $72: 309$

Williains H, McBirney AR (1979) Volcanology. Freeman, Cooper Co., San Francisco

Wolff JA, Wörner G, Blake S (1990) Gradients in physical parameters in zoned felsic magma bodies: implications for evolution and eruptive withdrawal. J Volcanol Geothem Res 43:37-55

Wood SH (1977) Distribution, correlation, and radiocarbon dating of late Holocene tephra, Mono and Inyo craters, eastern California. Geol Soc Am Bull 88:89-95

Editorial responsibility: J. Patchett 